Portland State University

PDXScholar

1992

\title{
Multidimensionality of Power Use in Organizations and its Correlates
}

Weizhong Dong

Portland State University

Follow this and additional works at: https://pdxscholar.library.pdx.edu/open_access_etds

Part of the Industrial and Organizational Psychology Commons

Let us know how access to this document benefits you.

Recommended Citation

Dong, Weizhong, "Multidimensionality of Power Use in Organizations and its Correlates" (1992).

Dissertations and Theses. Paper 4219.

https://doi.org/10.15760/etd.6107

This Thesis is brought to you for free and open access. It has been accepted for inclusion in Dissertations and Theses by an authorized administrator of PDXScholar. Please contact us if we can make this document more accessible: pdxscholar@pdx.edu. 
AN ABSTRACT OF THE THESIS OF Weizhong Dong for the Master of Arts in Psychology presented August 14, 1992.

Title: Multidimensionality of Power Use in Organizations and Its Correlates.

APPROVED BY THE MEMBERS OF THE THESIS COMMITTEE:

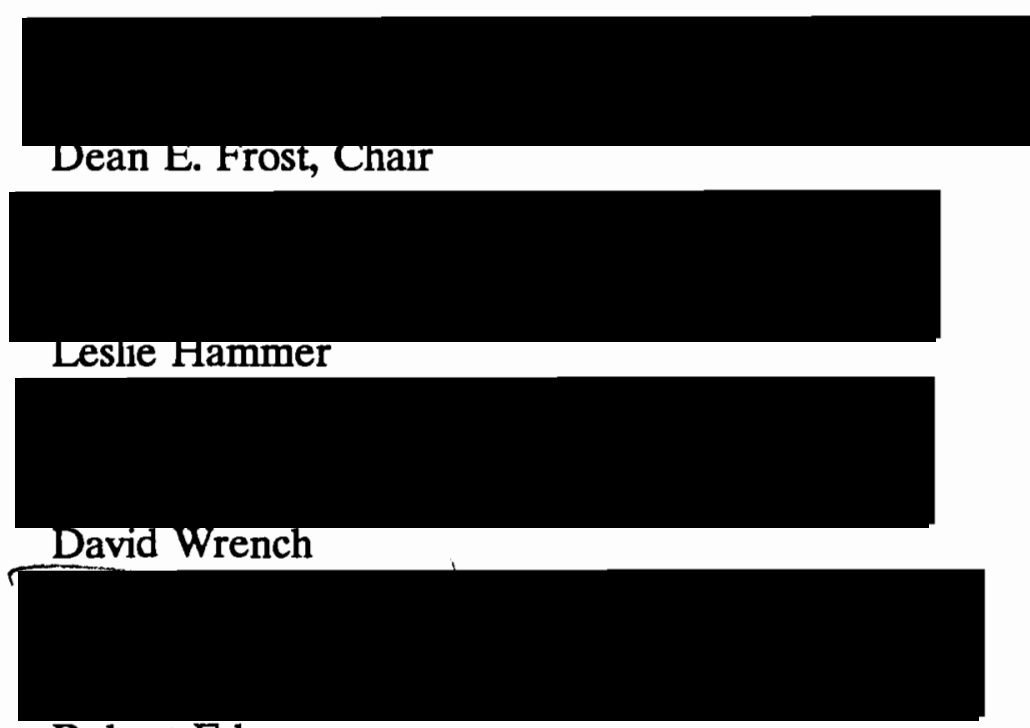

Robert Eder

The present study was conducted to examine power use patterns and general power use strategies in organizations multidimensionally (i.e., downward, upward, and lateral directions of power use), to extend and explain previous findings by Kipnis et al. (1980), with reference to situational effects on multidimensional power use. The samples in this study consist of 230 full-time managers who were from eight local businesses, and a second sample of 140 college students who worked over 15 hours a week at the time of the study. Two exploratory factor 
analyses resulted in five commonly used power patterns and two general power use strategies based on the eight factors found from Kipnis et al. (1980) factor analysis. Significant differences between the manager's level and manager's power tactics use were not found in downward, upward, or lateral power tactics use when three corresponding MANOVA analyses were conducted. Two different measures of work unit size were used, and the relationship between the work unit size and manager's power tactics use was significant when tested by a stepwise multiple regression analysis. A final multivariate analysis with repeated measures found no significant difference between the two response formats used on the questionnaires given to the college student sample. The important implications and contributions of the present study are discussed as well as future research directions. 
MULTIDIMENSIONALITY OF POWER USE IN ORGANIZATIONS AND ITS CORRELATES

\author{
by \\ WEIZHONG DONG
}

A thesis submitted in partial fulfillment of the requirements for the degree of

\author{
MASTER OF ARTS \\ in \\ PSYCHOLOGY
}

Portland State University

1992 


\section{TO THE OFFICE OF GRADUATE STUDIES:}

The members of the Committee approve the thesis of Weizhong Dong presented August 14, 1992.

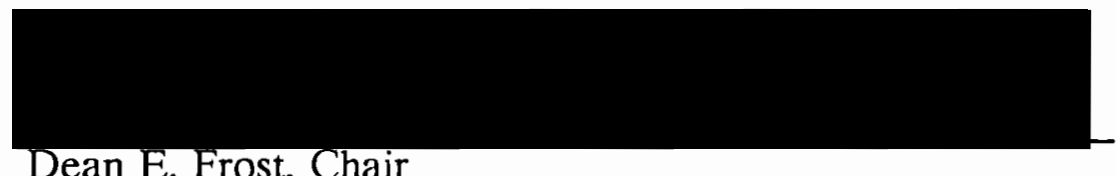

Dean E. Frost, Chair

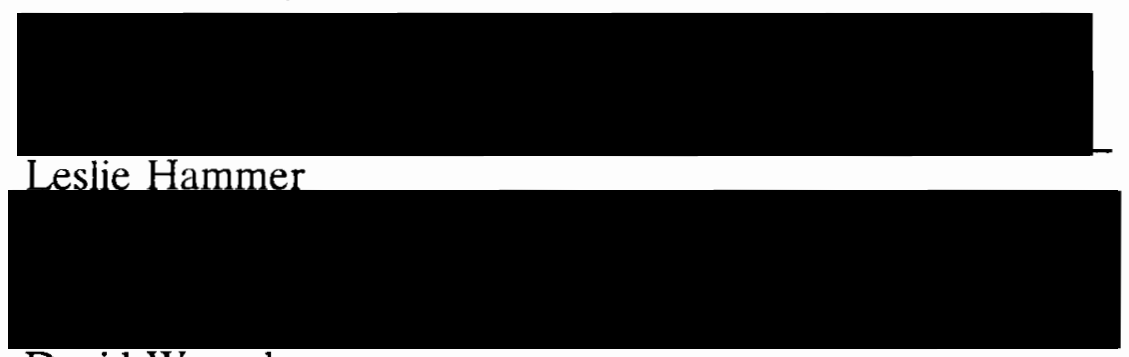

David Wrench

Robert Eder

APPROVED:

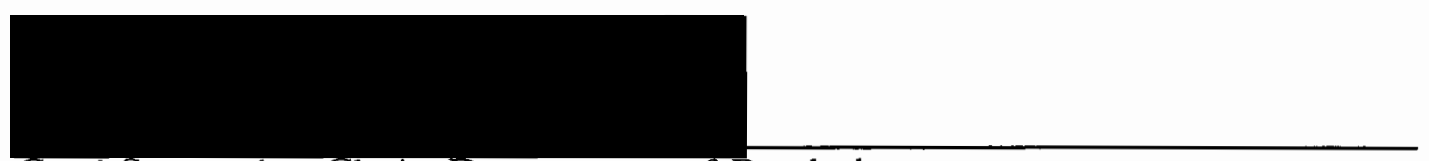

Cord Sengstake, Chair, Department of Psychology

Roy W. Kqgch, Vice Provost for Graduate Studies and Research 


\section{TABLE OF CONTENTS}

PAGE

LIST OF TABLES $\ldots \ldots \ldots \ldots \ldots \ldots \ldots \ldots \ldots \ldots \ldots \ldots, \mathbf{v}$

LIST OF FIGURES $\ldots \ldots \ldots \ldots \ldots \ldots \ldots \ldots \ldots \ldots \ldots$ vi

INTRODUCTION $\ldots \ldots \ldots \ldots \ldots \ldots \ldots \ldots \ldots \ldots \ldots \ldots \ldots \ldots$

THEORETICAL BACKGROUND OF POWER USE $\ldots \ldots \ldots \ldots \ldots 2$

Downward Power Use..$\ldots \ldots \ldots \ldots \ldots \ldots \ldots \ldots$

Upward Power Use.$\ldots \ldots \ldots \ldots \ldots \ldots \ldots \ldots \ldots \ldots$

Lateral Power Use ........................... 5

A Neglected Area: Multidimensionality of Power Use ........... 5

POWER IN MANAGEMENT HIERACHY $\ldots \ldots \ldots \ldots \ldots \ldots \ldots \ldots$

Top Management $\ldots \ldots \ldots \ldots \ldots \ldots \ldots \ldots \ldots \ldots \ldots \ldots \ldots \ldots \ldots$

Middle Managers.$\ldots \ldots \ldots \ldots \ldots \ldots \ldots \ldots \ldots \ldots \ldots \ldots$

Lower Level Supervisors ....................... 13

UNIT SIZE AND POWER USE $\ldots \ldots \ldots \ldots \ldots \ldots \ldots \ldots \ldots \ldots$

PURPOSES AND HYPOTHESES $\ldots \ldots \ldots \ldots \ldots \ldots \ldots \ldots \ldots \ldots . \ldots \ldots$

Purposes of the Present Research . . . . . . . . . . . . . . . . 17

Hypotheses . . . . . . . . . . . . . . . . . . . . . 20

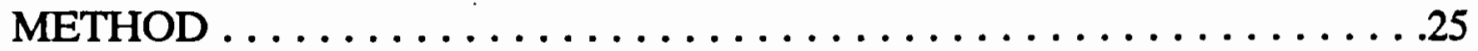

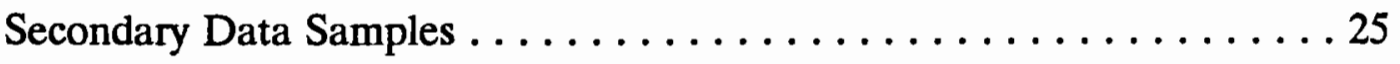




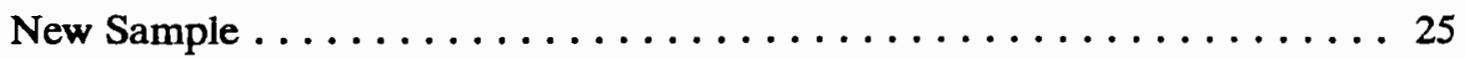

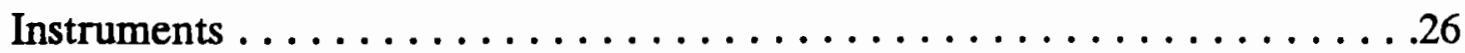

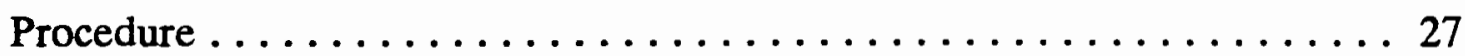

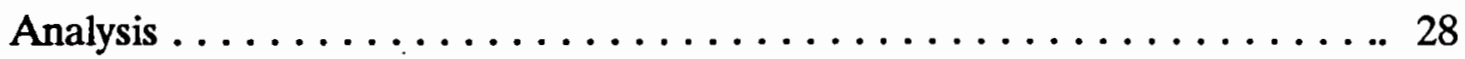

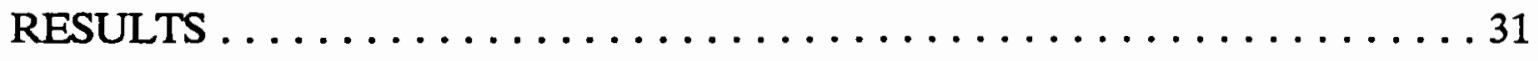

DISCUSSION .............................. 51

Power Tactic Use Patterns and General Strategies . . . . . . . . . . 52

Strong Tactics Within Group

Strong Tactics Outside Group

Rationality

Support Seeking

Exchange

Weak Indirect Tactics (or Human Relations Tactics)

Strong Direct Tactics (or Task-oriented Tactics)

Management Hierachy Effects on Power Tactics Use .......... 56

Work Unit Size and Power Tactics Use . . . . . . . . . . . 57

Response Formats of Power Tactics Use Measure . . . . . . . . . 58

The Implications of the Study $\ldots \ldots \ldots \ldots \ldots \ldots \ldots \ldots$

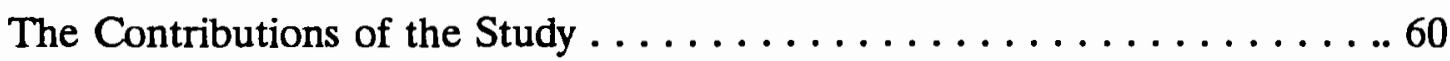

Recomendations for Future Research.$\ldots \ldots \ldots \ldots \ldots$

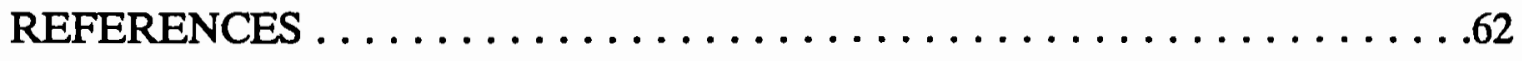

APPENDICES

A KIPNIS ET AL. ORIGINAL QUESTIONNAIRE ..........68

B TWO FORMS OF POWER USE QUESTIONNAIRE . . . . . . . 71 


\section{LIST OF TABLES}

TABLE

PAGE

I French and Raven Power Typology $\ldots \ldots \ldots \ldots \ldots$

II Alpha, Scale Means, and Standard Deviations for Tactics Scales

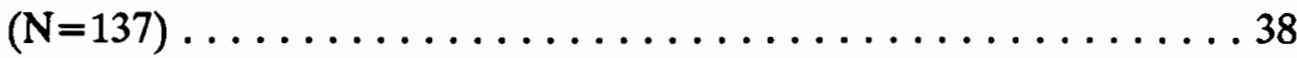

III Scale Inter-correlations $(\mathrm{N}=137) \ldots \ldots \ldots \ldots \ldots \ldots \ldots \ldots \ldots \ldots$

IV Inter-factor Correlations $\ldots \ldots \ldots \ldots \ldots \ldots \ldots \ldots \ldots \ldots \ldots \ldots$

V Rotated Factor Pattern, Eigenvalues, and Variances Accounted for 42

VI Rotated Factor Pattern, Eigenvalues, and Variances Accounted for (The Second Order Factor Analysis) $\ldots \ldots \ldots \ldots \ldots \ldots \ldots \ldots$

VII Tactic Scale Means Reported by Middle Managers vs. Lower-level Supervisors Analyzed by Directions of Influence . . . . . . . 44

VIII Multiple Regression Analysis of Power Tactics Scales Predicting Two Unit Size Measures . . . . . . . . . . . . . . 46

IX Mean Job Satisfaction Rating by Power Tactic Scale

Rating Format $\ldots \ldots \ldots \ldots \ldots \ldots \ldots \ldots \ldots \ldots \ldots$

X Second-order Correlations between Tactics Used and Overall Job

Satisfaction $(\mathrm{N}=70)$ by Rating Scale Format $\ldots \ldots \ldots \ldots \ldots \ldots 48$

XI Multivariate Analysis of the Differences between

Agreement Format and Frequency Format with Tactic Scales as

Repeated Measurements $(\mathrm{N}=140)$ 


\section{LIST OF FIGURES}

FIGURE

PAGE

1. Eight Overall Factors and Item Variables $\ldots \ldots \ldots \ldots \ldots \ldots$

2. Comparison of Scale Means between Agreement Format and Frequency Format $\ldots \ldots \ldots \ldots \ldots \ldots \ldots$ 


\section{INTRODUCTION}

Power, a fancy yet puzzling word, has been of concern to philosophers, priests, and kings since the beginning of civilization. Who can influence whom obviously depends on who is more powerful and who is less so (Bass, 1990). What is power? Many definitions exist. Bass (1990) defined power as " a force underlying social exchanges in which the dependent person in the exchange relationship has less power and the person with more power is able to obtain compliance with his or her wishes" (pp. 437) (i.e., a behavioral emphasis). Power is defined by French and Raven (1959) as the potential influence of agent over some person (i.e., a behavioral and attitudinal emphasis). Furthermore, sometimes power refers to the agent's influence over a single target person (French \& Raven, 1959), and other times power is measured in relation to multiple target persons (Rahim, 1989).

Most definitions of power indicate that power is the capability of one social actor to overcome resistance in achieving a desired objective or result, in which definition a social actor means an individual, subunit, or organization (Pfeffer, 1981). For the purpose of the present study, I modify Yukl's (1989) definition of power which only concerns an agent's potential influence as an agent's potential and actual influence over the attitudes and behavior of one or more designated target persons. I am specifically concerned with workgroup leaders' use of social power in influencing their coworkers in organizational settings. 


\section{THEORETICAL BACKGROUND OF POWER USE}

\section{DOWNWARD POWER USE}

Power is one of the most important determinants of leadership effectiveness (Yukl \& Falbe, 1990), and the concept is one of social psychology's major contributions to the study of leadership and social influence in organizations (Stahelski \& Frost, 1989). Despite the long history of power studies, French and Raven in 1959 were the first to propose a typology of power as a testable theory. This typology and the corresponding definitions are listed in Table I. Since then, the five-base typology has become a popular conceptualization of social power. However, most initial empirical studies based on this typology had vital problems.

In the late 60's and early 70's, studies by Bachman, Smith, and Slesinger (1966), Student (1968), and Thamhain and Gemill (1974) developed single item scales to measure French and Raven's (1959) five power bases. These measures had severe content validity problems. The social desirability response bias and forced intercorrelations between the bases of power (i.e., requiring respondents to rank-order the bases leads to some correlations always existing between the measures) are two additional major problems in most power base studies (Podsakoff \& Schriesheim, 1985).

Trying to solve these problems, Hinkin and Schriesheim (1989) developed a new measure with multiple items for each power base scale. Unfortunately, the 
problems of social desirability and attributional bias still remain. In the same period, Frost and Stahelski (1988) and Stahelski, Frost, and Patch (1989) tried a different approach by using behavioral reports from organizational leaders as a measure to test French and Raven's (1959) theoretical framework, as suggested by Podsakoff and Schriesheim (1985). As the result, they successfully minimized the social desirability and attributional biases. This innovative measure can be effectively used in future power research.

All the above studies concern power use in a downward relationship, namely, power used by leaders to attempt to influence their subordinates. As Pfeffer in 1981 pointed out, most studies of power in organizations have focused on such a vertical dimension, the power of leaders over subordinates, or bosses over employees. Besides the research mentioned previously, there are a large number of studies involving downward power use (Dunne, Stahl \& Melhart, 1978; Falbo, 1977; Goodstadt \& Kipnis, 1970; Graen, Cashman, Ginsburg \& Schiemann, 1977; Ivancevich, 1970; Kipnis \& Cosentino, 1969; Kipnis \& Lane, 1962; Nystrom, 1990; Pfeffer \& Salancik, 1975; Podsakoff, 1982; Podsakoff, Todor, Grover \& Huber, 1984; Rahim, 1989; Yukl \& Falbe, 1991). The empirical research of downward power use started immediately after French and Raven's (1959) typology, and this power base model is still receiving the most attention from current researchers (Yukl \& Falbe, 1991). 


\section{UPWARD POWER USE}

Available literature suggests that most research has been focused on downward power strategies, and attempts made to probe upward methods are relatively sparse. Collins and Raven (1969) stated that power in organizations is much more complex than that in animal and other simple social structures in which power is unidimensional. In organizations, downward power is not the only dimension. Strategies of upward influence are now receiving more attention from researchers (Hollander \& Offermann, 1990).

In 1962, Mechanic discussed how such factors as expertise, effort, coalitions, and location served to increase the power of lower-level participants. These bases of social power enable the lower-level participants to exert influence over higherranking individuals within an organization. However, he did not offer empirical research to support his argument. Fourteen years later, Cashman, Dansereau, Graen, and Haga (1976) extended the vertical linkage theory in their research to include a leader's upward exchange relationship as well as the downward relationships, and they studied vertical dyads at two levels instead of only one level. They found that subordinates of the vertical linkage who had positive relationships with their bosses experienced fewer severe job problems, received more leadership attention, and showed higher job satisfaction; leaders who had ingroup relationships with their superiors received more inside information, greater influence in decision making, higher degree of job latitude, and greater support from their superiors. Behavioral strategies for influencing immediate superiors and 
upward influence processes were later studied by Singh (1988). The results indicated that the leaders who were more concerned with their duty believed in rather straight-forward dealing with their superiors than covert strategies such as personalized help and pseudo-dependence.

\section{LATERAL POWER USE}

In organizations, the action component is often stereotyped as the interface between superiors and subordinates. However, reality is far different. "Empirical studies show managers spending the majority of their time outside the simple vertical channel prescribed by the hierarchy" (Sayles, 1979, pp.123). Although the importance of lateral power influence was recognized by Landsberger as early as 1957, empirical research just began in the middle of the 1970's and has been continuing (Enz, 1988; Osborn \& Hunt, 1974). Most recently, Yukl (1991) developed a measure to study power use consisting of downward and lateral power uses in organizations.

\section{A NEGLECTED AREA: MULTIDIMENSIONALITY OF POWER USE}

In the early of 1980 's, researchers began to realize that power in organizations should be studied multidimensionally (Kanter, 1982; Kaplan, 1984). Unfortunately, only two empirical studies are available in the existing literature (Kipnis, Schmidt \& Wilkinson, 1980; Yukl \& Falbe, 1990). The present research is trying to enrich the field of the multidimensionality of power use and to improve our 
understanding of complicated power relations.

"One of the most important determinants of managerial effectiveness is success in influencing subordinates, peers, and superiors" (Yukl \& Falbe, 1990, pp. 132). This is especially true for those leaders who are at middle levels of the organizational hierarchy. Leaders at middle level often require data, agreements, and resources of wider scope than routine operations demand. Sometimes they ask peers for "pledges" of money, staff or coalition, other times, they need to negotiate for executives' support in order to complete their tasks (Kanter, 1982). Nevertheless, power influence directed toward subordinates, superiors, and peers as a multidimensional network of power use in organizations has been neglected by researchers even though there are some theoretical articles clearly stating that this network is essential (Allen \& Porter, 1983; Kanter, 1982; Kaplan, 1984; Pfeffer, 1981; Yukl, 1989).

In the exploratory study by Kipnis, Schmidt and Wilkinson (1980), organizational leaders who were taking part-time graduate business courses were asked to describe actual incidents in which they attempted to influence the behavior of subordinates, peers, and supervisors. Based on these descriptions, a questionnaire was constructed containing 58 questions about influence tactics use. By using the statistical technique of exploratory factor analysis on the entire sample, Kipnis and his colleagues found eight factors or tactics of influence (see Figure $1 \&$ Appendix A) which are used differently by leaders depending on the direction of influence. This study was an important initial attempt at understanding 
the multidimensionality of power use in organizations.

As with all exploratory research, there are also some potential problems in the Kipnis et al. (1980) study. First, the items in their questionnaire were derived from examples described by college students, which makes the generalizability of the research questionable. Second, these graduate business students, although they were working as organizational leaders, were from many different organizations. The organizational cultures in which they were working were different, and this difference may affect their multidirectional power use. Third, Kipnis and his colleagues used three different samples to test power use directed toward downward, upward, and lateral directions, therefore, the different patterns of power use tactics at the three directions may be confounded with such factors as individual style of power use. Fourth, as Yukl and Falbe (1990) noticed, the research examined only self-perception of influence tactics. The possibility of systematic biases in these self-reports was not addressed.

Yukl and Falbe (1990) tried to replicate the Kipnis et al. (1980) study and extend the research to include additional types of influence behavior. They used evening MBA students and organizational leaders who were attending management development courses as subjects, and successfully replicated most of the results founded by Kipnis and his colleagues. However, the earlier findings for differences in upward, downward, and lateral use of power were only partially supported. No significant directional differences were found for the factor of Rational Persuasion, and the findings of the directional differences for the factors 
of Exchange and Ingratiation were also inconsistent in these two studies.

Yukl and Falbe's (1990) study generally has the same problems as Kipnis et al.'s (1980). Additionally, the questions of organizational hierarchical level and unit size were not answered. Therefore, in the present study, I use actual leaders in organizations as subjects, and discuss the effects of leader's position level and unit size on the use of influence tactics at multidirectional levels. 
TABLE I

FRENCH AND RAVEN POWER TYPOLOGY

Reward Power

Coercive Power

Legitimate Power

Expert Power

Referent Power
The target person complies in order to obtain rewards he or she believes are controlled by the agent.

The target person complies in order to avoid punishments he or she believes are controlled by the agent.

The target person complies because he or she believes that agent has the right to make the request and the target person has the obligation to comply.

The target person complies because he or she believes that the agent has special knowledge about the best way to do something.

The target person complies because he or she admires or identifies with the agent and wants to gain the agent's approval.

Note: Taken from Table 3-1, pp. 35. Yukl, 1989. 

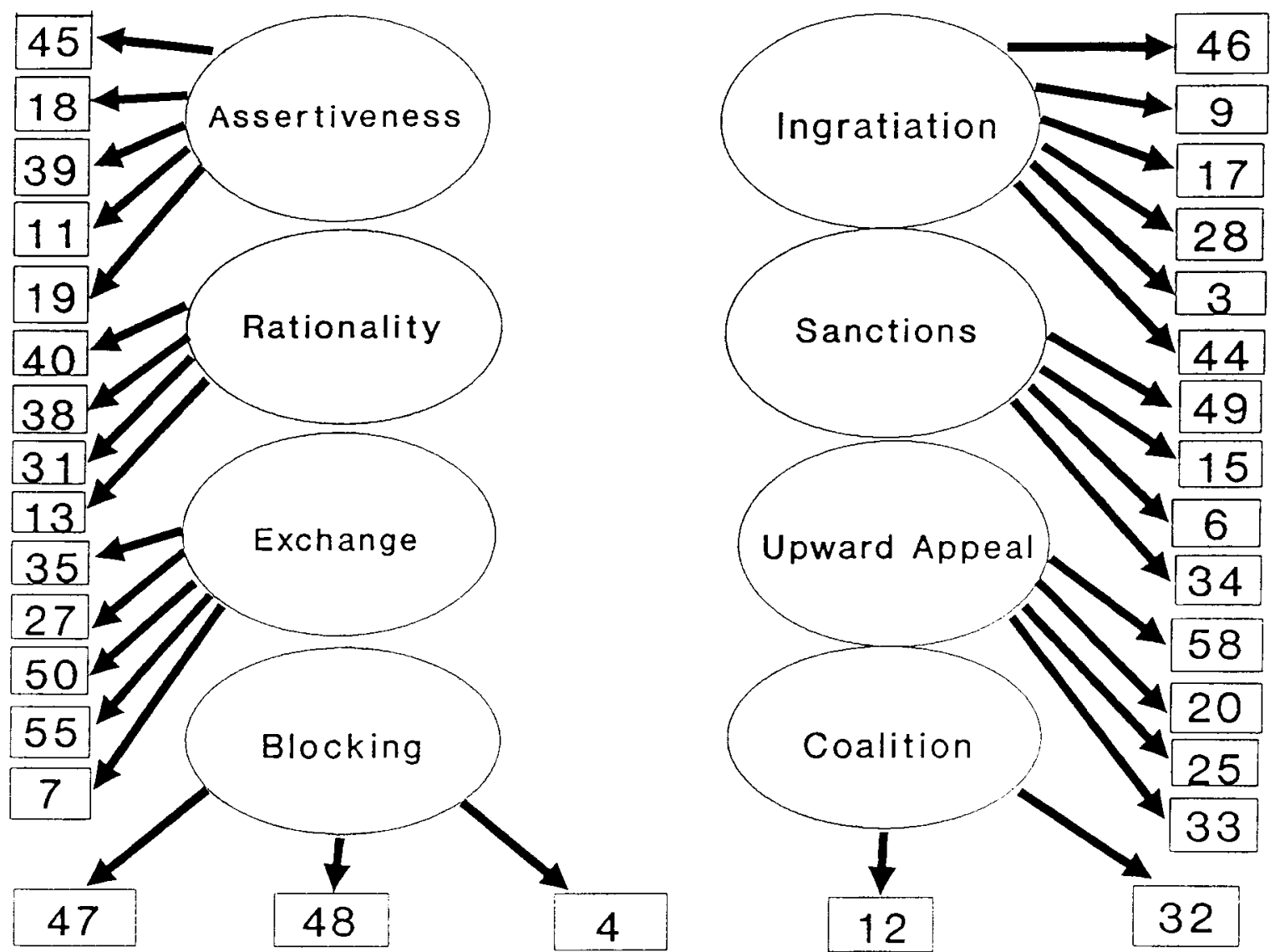

Eigure 1. Eight Overall Factors and Item Variables. 


\section{POWER IN MANAGEMENT HIERARCHY}

\section{TOP MANAGEMENT}

The research on the power strategies used by top managers is very sparse. This sparsity might be due to the difficulty in collecting empirical data at the top level of management.

According to Isenberg (1984), top managers mainly think about general issues in organizations, and their major task is to influence others to think about the business and implement organizational objectives. Research shows that top managers have a strong pattern of reliance on their own subordinates (Blankenship \& Miles, 1968). Therefore, their primary influence tactics tend to be downward in the organization and lateral into the outside world (Kaplan, 1984). A thorough discussion about the power use at the top-level of management is beyond the scope of the present study since the main concern of the present research is on multidimensionality of the power use within organizations in terms of upward, downward, and lateral directions among middle level managers and lower level supervisors.

\section{MIDDLE MANAGERS}

Managers are responsible for both their superiors and their subordinates. In order to accomplish their tasks, they also need to build coalitions and gain 
coordination to obtain essential extra resources.

Upward influence is important for managers in terms of obtaining resources and support from top management. An early study conducted by Pelz (1952) revealed that high upward influence of leaders is related to significantly greater subordinate satisfaction. In their study, James, Ginsburg and Schiemann (1977) assessed a panel of 103 managerial dyads employed in service organizations regarding the quality of their upward linking-pin -- the perceived effectiveness of upward influence. They found that leaders who can successfully influence their superiors received more latitude, support, and attention. This quality of the linking-pin is related to the quality of working life in the lower dyad, the relationship between the leaders and their subordinates. In addition, leaders who experience low-quality exchange with their own superiors tend to feel little commitment toward their organizations whereas leaders with high-quality vertical relationships express strong organizational commitment (Nystrom, 1990).

Managers' success stems mainly from their subordinates' job performance, satisfaction, and commitment, and therefore downward influence is essential. A large number of empirical studies show that proper use of downward influence is significantly related to subordinates' performance (Bachman et al., 1966; Ivancevich \& Donnelly, 1970; Sheridan \& Vredenburgh, 1978; Slocum, 1970; Student, 1968; Thamhain \& Gemmill, 1974), satisfaction (Bachman, 1968; Bachman et al., 1966; Bachman et al., 1968; Busch, 1980; Burke \& Wilcox, 1971; Cope, 1972; Dunne, Stahl \& Melhart, 1978; Ivancevich, 1970; Martin \& Hunt, 
1980; Slocum, 1970), and turnover and commitment (Bachman, 1968; Busch, 1980; Ivancevich \& Donnelly, 1970; Martin \& Hunt, 1980; Student, 1968; Warren, 1968).

Managers do more than just interact with superiors and subordinates. Horizontal or lateral flow in or across organizations is just as important and as frequent as any flow of authoritative orders up and down the organization, and the existence of horizontal work flows at all levels can be seen most vividly in industrial organizations (Landsberger, 1961). Lateral interactions by the managers may also have an important impact on employee performance and satisfaction. Although empirical studies addressing the importance of lateral relations are rare, Sayles (1964) asserted that more developed and sophisticated lateral interaction with other managers was likely to substantially increase sub-systems' performance and satisfaction. Osborn (1971) found that lateral relationships predicted subsystems' performance, and also were positively related to employee satisfaction criteria (Osborn \& Hunt, 1974).

Managers at middle level are a focal point in organizations, they have to learn how to appropriately exert their influence multidimensionally in order to have their jobs done efficiently.

\section{LOWER-LEVEL SUPERVISORS}

Being a supervisor, he wieghts upward, downward and lateral relationships differently from those who are at higher levels. Blankenship and Miles (1968) 
conducted research on the association between hierarchical position and managerial decision behavior. They found that supervisors did not appear to rely on their subordinates for initiation of action or suggestions, but took their guidance from above. They were required and expected to consult with their superiors before proceeding on most issues. It seems true that supervisors pay more attention to upward and probably to lateral relationships than to downward relationships. Therefore, they might frequently use punitive behavior toward their subordinates in terms of referring them to the middle or higher level of management, which is especially true when the supervisors have less experience and self-confidence (Kipnis \& Cosentino, 1969).

As we have seen, leaders at different levels of the organizational hierarchy have different foci on upward, downward and lateral influences. They use different power tactics to influence their superiors, peers, and subordinates. In their research of multidimensional power use, Kipnis and his colleagues (1980) reported that the leader's level in the organization was closely associated with the use of influence tactics. However, Yukl and Falbe (1990) in their replication study did not examine the effect of organizational hierarchy on power use. This hierarchy effect on multidimensional influence behavior is further addressed in the present study. As pointed out above, middle level managers and lower level supervisors should be targeted primarily. 


\section{UNIT SIZE AND POWER USE}

There is an evidence that differences in unit size affect power use in organizations. According to Mintzberg (1979), a small unit size allows a leader to monitor and supervise the unit's activities more closely, and to be more readily available for consultation and advice. Leaders supervising large groups are found to use more official warnings and rely on more referral and report, and less on their expert power and direct supervision than did leaders supervising smaller groups (Goodstadt \& Kipnis, 1970; Kipnis \& Cosentino, 1969; Kipnis \& Lane, 1962). Increasing group size is positively related to the increase of leader coercive power use (Stahelski, Frost \& Patch, 1989).

The implication of work unit size for leader behavior has been investigated in several types of research. According to Yukl (1989), interpretation of the results is complicated by the fact that group size is often confounded with other aspects of the situations, such as task complexity and degree of role interdependence among subordinates. A further complication is that size can be measured in a variety of ways which may not be consistent. However, in spite of these complications, the evidence of the effect of unit size on leader's power use is obvious. Because there is less time available in large groups to provide support and encouragement to each subordinate and to engage in interpersonal behavior necessary for maintaining effective relationships with subordinates (Ford, 1981), and because 
good performance by subordinates is less likely to be recognized and rewarded (Goodstadt \& Kipnis, 1970), leaders usually deal with subordinates in a formalized and impersonal manner (Kipnis \& Cosentino, 1969; Kipnis \& Lane, 1962).

In an exploratory study of multidimensional power use, Kipnis and his colleagues (1980) also found that unit size was related to the use of tactics on subordinates. In large units, leaders tend to use Assertiveness, Sanctions, and Upward Appeal to influence their subordinates. In the replication study, Yukl and Falbe (1990) failed to address the issue of unit size effect on leader's power use. The effects of unit size on power use tactics and the different measures of unit size are further examined in the present study. 


\section{PURPOSES AND HYPOTHESES}

\section{PURPOSES OF THE PRESENT RESEARCH}

As I have discussed, traditional power research focused on the perceptions that subordinates hold about their leaders' potential power use, which are likely to be contaminated by social desirability biases (i.e., subordinates report in a way that they think their responses are socially desired) and attributional biases. Kipnis et al. (1980), Frost and Stahelski (1988), and Stahelski, Frost, and Patch (1989) took another approach and directly asked organizational leaders how often they actually used certain tactics to influence their superiors, peers and subordinates. This approach is unique because (1) self-report by leaders instead of subordinates eliminates subordinates' attributional bias (i.e., subordinates' attribution about their leaders' potential power use), (2) response scale anchors are actual frequency reports by leaders rather than potential actions perceived by subordinates so that the effect of a different type of potential social desirability bias is examined.

The development of theories and research on power use in organizations has moved to multidimensional analysis from unidimensionality. Kipnis and his colleagues (1980) used the above approach to study the multidimensionality of power use in organizations, which is considered an important exploratory study in the area of power use. However, among the limitations mentioned previously, one 
of them is that they did not examine the relationships among power use tactics across the three directions, downward, upward, and lateral.

Up until now, only one study conducted by Yukl and Falbe (1990) has attempted to confirm the Kipnis et al. study. Most of their findings are consistent with Kipnis et al.'s, however, Yukl and Falbe have not done a true replication study. First of ail, they did not do a factor analysis to confirm the eight factors found by Kipnis et al. (1980). Secondly, they arbitrarily dropped out two factors, Sanction and Blocking, which had a reasonable number of representative items, and their reliability coefficients were .73 and .53 , respectively, in the Kipnis et al. findings. Additionally, Yukl and Falbe added two factors of their own, Inspirational Appeals and Consultation Tactics, without providing any empirical reason. They also changed the names of factors defined by Kipnis et al., and the meaning of each factor was not exactly the same as those in the definitions of Kipnis et al. (e.g., items were re-written by Yukl and Falbe). Although Yukl and Falbe recognized the importance of studying the multidimensionality of power use in organizations, they went in a different direction from Kipnis et al. without a solid empirical foundation. The present study use the Kipnis et al. questionnaire to study full-time leaders in organizations who are used as a single sample to examine the three directions of power use and the relationships among the power tactics across the three directions; downward, upward and lateral.

Yukl and Falbe (1990) in their study did not answer questions about situational effects, such as organizational hierarchy effects and unit size, both of 
which were addressed in the study of Kipnis et al. (1980). The consistency or discrepancy in results on power use due to place in the management hierarchy or unit size is obtained so that differences between the Kipnis et al. findings and the findings of the present study can be discussed.

The relationships among influence tactics across the directions were not mentioned in both Kipnis et al. (1980) and Yukl and Falbe (1990) studies. The questions of whether there are any relationships among power tactics across the three directions of upward, downward and lateral, and whether influence tactics used toward subordinates correlate with those used toward superiors and peers are answered in the present research.

All these discussions make it imperative to conduct the present study. The purposes of the study are to (1) examine power use patterns multidimensionally based on the overall eight factors of Kipnis et al., (2) verify the findings of Kipnis et al. by administering their questionnaire to full-time leaders in organizational settings, (3) examine situational effects on multidimensional power use tactics, such as work unit size, (4) test the effect of a possible social desirability bias, and (5) concurrently validate the different response formats of the questionnaire constructed by Kipnis et al. by correlating their scales with job satisfaction measures. 


\section{HYPOTHESES}

The present study administers the Kipnis et al. questionnaire to leaders in organizational settings. Kipnis and his colleagues conducted an exploratory factor analysis on the entire sample which consisted of 745 part-time MBA students, and found overall eight factors. They also did three separate factor analyses on their three separate sub-samples which were obtained by dividing the entire sample into three groups corresponding to the three different directions (i.e., downward, upward, lateral). These findings indicated that leaders tended to use different power tactics to influence the target persons at different levels (i.e., subordinates, peers, superiors).

In the present study, I use 230 full-time organizational leaders as a sample to assess their use of influence tactics. The existence of eight factors representing eight power tactics found from the Kipnis et al. overall factor analysis is assumed in each direction of influence attempt in this study.

An individual may have a certain pattern of using power influence tactics in terms of downward, upward, and lateral attempts. So far, no research on power use has reported any patterns of power tactics use across downward, upward, and lateral directions (Kipnis et al. and Yukl and Falbe used separate samples for each directional assessment). However, the Kipnis et al. questionnaire is the only system to allow to test these patterns. In their study, Graen, Cashman, Ginsburg, and Schiemann (1977) reported that the quality of a leader's relationship with his/her superiors was related to the quality of the relationship with his/her 
subordinates. Therefore, a leader who has in-group relationships with his/her superiors by exerting certain influence tactics may build the same relationships with his/her subordinates by using the same tactics as he/she uses or different from what he/she uses toward the superiors. For example, a leader's use of Ingratiation tactic towards his/her superiors may be positively related to his/her use of Sanctions or Ingratiation tactic towards his/her subordinates in order to build desired relationships with his/her superiors or subordinates.

Because I use the same subjects in this study to respond to all the three directions of tactics use (i.e., downward, upward, and lateral), an individual may have a certain pattern of using power tactics to influence his/her superiors, subordinates, and peers.

HYPOTHESIS 1: The findings of Kipnis et al. that leaders at middle level use more Rationality and Assertiveness in both downward and upward directions, Sanctions and Upward Appeals in downward influence attempts than leaders at lower level will be replicated. The relationship between manager's level and tactics use in lateral direction will also be tested.

HYPOTHESIS 2: The findings of Kipnis et al. that leaders of larger groups use more Assertiveness, Sanctions, and Upward Appeals toward their subordinates will be replicated. Whether size of work unit correlates with lateral or upward tactics used will also be determined. The relationships between the two measures of unit size (number of employees v.s. number of subordinates) and leader power tactics use will be examined. 
Because the unit size can be measured either by the number of employees in a leader's work unit or by the number of subordinates whom the leader is directly supervising as discussed by Yukl (1989), the relationships between these two measures of group size and leader power tactics use were examined.

Previous research has shown clear evidence that positions in the management hierarchy and unit size have significant effects on power use tactics. Supervisors tend to use punitive behaviors more often than do managers (Kipnis \& Cosentino, 1969; Kipnis et al., 1980): Leaders in larger work units are more likely to use formalized and impersonal power tactics to influence their target persons than those in smaller work units (Goodstadt \& Kipnis, 1970; Kipnis \& Cosentino, 1969; Kipnis et al., 1980; Kipnis \& Lane, 1962; Stahelski, Frost \& Patch, 1989). However, whether there is a relationship between work unit size and upward v.s. lateral power tactics use has not been reported by any previous study. The different measures of unit size also have not been applied in power research although they were argued by Yukl (1989). The present study examines these negalected aspects in the study of power tactics use.

HYPOTHESIS 3: Partial correlations between the total scores of the Kipnis et al. five scales of downward tactics and overall job satisfaction ratings will be significantly different when the two response formats are compared. The correlation between the questionnaire scales with agreement format and overall job satisfaction will be lower than that between the scales with the behavioral frequency response format and overall job satisfaction. 
A second study using a new sample is included here. Leaders' subordinates reported use of power tactics by the leaders toward others. By using the Kipnis et al. questionnaire scales with the behavioral frequency response format and the Hinkin and Schriesheim agreement format, I am able to compare the correlations of each of the different formats with subordinates overall job satisfaction by controlling the effects of work unit size. Overall job satisfaction was measured by the Minnesota Satisfaction Questionnaire and was used in the criterion-related validity analysis because satisfaction is a traditional dependent variable in power research (cf. Bass, 1990; Yukl, 1989) and because satisfaction has been shown to be related to other important variables such as performance and commitment (cf. Locke, 1976).

HYPOTHESIS 4: Rank orderings for the 5 downward tactic scales will be significantly different for responses collected on the frequency response format compared to the agreement response format.

Two forms of the Kipnis et al. questionnaire were used: one had a behavioral frequency response format, and the other used agreement response scales (see Appendix B). By comparing the results of the two forms, I am able to test for differences in the results associated with using behavioral frequency anchors (as used by the Kipnis et al. in 1980 and the Frost and Stahelski in 1988 and 1989 questionnaires) as compared to the more commonly used agreement scale (as used by the Hinkin and Schriesheim in 1989 questionnaire) which was criticized by Podsakoff and Schrieshem (1985). Using the behavioral frequency format makes 
the scale more valid because it is closer to an observable behavior, and it reduces the severity of social desirability and attributional biases. 


\section{METHOD}

\section{SECONDARY DATA SAMPLES}

The first sample consisted of 120 full-time employees of U.S. West

Communications Inc. All of them had management responsibilities. The second sample consisted of 110 full-time employees attending a management development workshop, and all of whom had management responsibilities in their current work assignments. Eight different organizations were represented, representing medium sized organizations (i.e., 100 to 500 employees in each) in a variety of industries.

These samples were combined and used as a single sample of 230 subjects in the present study.

\section{NEW SAMPLE}

The new sample consisted of 140 subjects, PSU students who worked at least 15 hours per week at the time of the study. This sample was used to test Hypothesis 3 and Hypothesis 4 only. The subjects rated their leaders' influence behaviors (i.e., respondents were the subordinates not the leader as in samples one and two). 


\section{INSTRUMENTS}

Respondents in the secondary data sample completed three different questionnaires representing the three forms of the Kipnis et al. (1980) influence tactics scales (i.e., downward, upward, and lateral tactics). All questionnaires had the same items but different instructions in terms of asking respondents to rate target persons of different status (i.e., subordinates, peers, superiors). Respondents also indicated whether they were first-level supervisors (i.e., their subordinates had no managerial responsibilities themselves) or whether they were middle-level managers (i.e., supervising subordinates who were managers themselves). The respondents also indicated the number of employees in their work unit and the number of subordinates whom they directly supervised within that work unit, or department.

The new sample received the Kipnis et al. (1980) five downward scales only. Two forms of the questionnaire were used (see Appendix 2). Form A representing the Kipnis et al. behavioral frequency format employs response scales indicating how often a respondent's leader uses certain tactics to influence others in his/her workgroup based on the respondent's recall. Form B representing the Hinkin and Schriesheim agreement format uses response scales indicating whether the respondent's leader could potentially perform the indicated behavior in the questionnaire based on the respondent's perception. Half of the sample responded to Form A, and the other half to Form B. The whole sample was also asked to respond to the Minnesota Job Satisfaction Questionnaire which was included in 
the both forms of the questionnaire. The respondents indicated the number of employees in their work unit and the number of subordinates whom they were directly supervising within that work unit. The hours per week the respondents worked were also collected.

\section{PROCEDURE}

In the secondary data sample, one group of respondents received the questionnaires through the company mail system with a cover letter providing instructions on how the questionnaires should be completed. Respondents also received a stamped, self-addressed envelope in which to return the completed questionnaire directly to the researchers via the U.S. Mail. The other group of respondents completed the questionnaires during a workshop presentation with instructions provided by a research assistant. Questionnaires were completed and returned during the workshop.

In the new sample, all respondents were given a brief description of the study and verbal assurance of the voluntary, anonymous, and confidential nature of the research after the classroom instructor's approval was sought. The two forms of the questionnaire were randomly distributed to the respondents, and the completed questionnaires were collected in class. 


\section{ANALYSIS}

Alpha coefficients were calculated for each factor or scale found by Kipnis et al. for each direction of influence: downward, upward, and lateral. Item scores of the respondents were summed to produce scale scores.

Patterns of power use were assessed by combining power tactics across the different directions and then the relationship between the patterns were examined by conducting an exploratory factor analysis. Thus, Kipnis et al.'s eight factors were assumed to exist in all the three directions, downward, upward, and lateral. Item scores were summed to produce the eight scale scores in each direction. A total 24 scale scores were computed to produce $24 \times 24$ correlation matrix which was then used for conducting an exploratory factor analysis. High scale loadings on a certain factor show a certain pattern of power use combining tactics of different directions. The relationships between power use patterns were examined by looking at inter-factor correlations.

To test HYPOTHESIS 1, three individual MANOVA were used corresponding to the three directional tactics uses (downward, upward, and lateral directions). The two management levels (managers v.s. supervisors) were used as an independent variable. The dependent variables were eight scales from Kipnis et al. (1980) pooled overall factor analysis. The significance of univariate tests was examined as well as the significance of multivariate tests.

A multiple regression analysis was used to test HYPOTHESIS 2 that work unit size relates to leaders tactics use in influencing their subordinates. 
Standardized weights of upward and lateral tactics relating to unit size was also examined. The regression analysis was conducted to test the difference between the unit sizes measured by the number of employees in a leader's work unit and measured by the number of subordinates whom the leader was directly supervising on leader power tactics use in the directions of downward, upward, and lateral. Stepwise regression with backward elimination technique was applied so that only tactics that are significant at five percent level were included in the final regression equations.

Because no previous theory and empirical study have attempted to predict the relationships between unit size and upward and lateral power tactics use, and the two measures of work unit size have never been used to study the relationships between the unit size and tactics use, this hypothesis test is very exploratory.

HYPOTHESIS 3 tests the concurrent validity of the two forms of the questionnaire by using overall job satisfaction as a criterion. The two forms of the questionnaire were distributed randomly to subjects. In order to ensure the similarity of the two response groups, I tested for significant differences of mean scores on the satisfaction measures between the groups. Two separate partial correlations were computed for the Kipnis et al. format with overall job satisfaction and the Hinkin and Schriesheim format with overall job satisfaction by controlling for the effect of work unit size. Overall job satisfaction was measured by the Minnesota Satisfaction Questionnaire. The significance of the differences between these correlations was assessed by transforming the correlation 
coefficients into standardized $\mathrm{Z}$ scores.

To test HYPOTHESIS 4, a multivariate analysis with tactic scales as repeated measures was conducted. Both the main effect of scale format and the interaction between format and specific tactic scales were examined, and the significance of the difference between the two response formats was also determined. 


\section{RESULTS}

Since eight commonly used tactics were found by Kipnis et al.'s (1980) overall factor analysis, these factors were assumed in the present study to be true in describing tactics directed at any target (i.e., downward, upward, and lateral influence attempts) which yielded a total of 24 tactic/target scales. However, descriptive statistics in the present study showed that five of the 24 tactics had minimal variance, and their scale means near their minimum values indicating that those five tactics were almost never used by leaders to influence their superiors, peers, and subordinates. These tactics were: Downward Blocking (Mean=3.219, Std Dev=.56, Min. value=3.0), Upward Sanctions $($ Mean=4.127, Std Dev=.61, Min. Value=4.0), Upward Blocking (Mean=3.267, Std Dev=.69, Min. Value=3.0), Lateral Sanctions $(\mathrm{Mean}=4.226$, Std $\mathrm{Dev}=.78$, Min. Value=4.0), and Lateral Blocking (Mean=3.316, Std Dev=.76, Min. Value=3.0). A frequency distribution showed that $80 \%$ to $95 \%$ of the respondents rated the five tactics as "Never being used." Therefore, these five tactics (or scales) were excluded from further statistical analyses.

Table II shows Cronbach alpha coefficients, means and standard deviations for each of 19 remaining tactics. The alpha coefficients, ranging from .879 to .895 , were much higher than those reported by Kipnis et al. (1980).

The intercorrelations of the 19 tactics is shown in Table III, excluding the 
observations with missing values.

An exploratory factor analysis was conducted based on this correlation matrix. A principal components model indicated five factors (given the rule of eigenvalue greater than one) as shown in Table V. A scree plot test also suggested a five factors solution. The common factor model with an iterated principal axis factoring technique was carried out with the rule of eigenvalue greater than zero. Although there were 11 eigenvalues greater than zero the scree plot showed a discontinuity between the 5th and the 6th eigenvalues (i.e., the cumulative variance accounted for by the first five factors is $100 \%$ ), the proportions of variances accounted for by each factor showed a significant difference between the first five factors (i.e., $57.3 \%, 15.5 \%, 13.6 \%, 8.1 \%, 5.6 \%$ ), and the rest. Furthermore, the five factor solution was the most interpretable.

Before the rotation, the percentage of total variance accounted for by Factor 1, Factor 2, Factor 3, Factor 4, and Factor 5 were 33\%, 9\%, 7.9\%, 4.7\% and 3.2\% respectively, and the percentage of common variance accounted for by the factors were $57.3 \%, 15.5 \%, 13.6 \%, 8.1 \%$, and $5.6 \%$. The total variance accounted for by the common factor model was $58.3 \%$.

However, the unrotated factor pattern did not show a simple loading structure. Due to the high inter-factor correlations as shown in Table IV, an oblique HarrisKaiser rotation was completed.

After the rotation, results in Table $\mathrm{V}$ show a clear simple structure. The percentage of total variance accounted for by Factor 1, Factor 2, Factor 3, Factor 
4, and Factor 5 were $9 \%, 15.4 \%, 20.2 \%, 23.4 \%$, and $29 \%$ respectively, and the percentage of common variance accounted for were $15.7 \%, 26.4 \%, 34.7 \%, 39.9 \%$, and $49.9 \%$. The final communality of each variable is also reported in Table V.

According to the simple structure in Table V, the variables of Downward Assertiveness and Downward Sanctions loaded on Factor 1 which can be interpreted as Leader's Strong Tactics Used Within the Group; Factor 2 had 3 high loadings, Upward Assertiveness, Upward Upward-appeal, and Lateral Assertiveness, representing Leader's Strong Tactics Used Outside the Group; the variables of Downward Rationality, Upward Rationality, Lateral Rationality loaded highly on Factor 3 which can be interpreted as Leader's Rationality; the Downward Upward-appeal, Downward Coalition, Upward Coalition, Lateral Upward-appeal, and Lateral Coalition loaded highly on Factor 4 which can be interpreted as Leader's Support Seeking; and finally Factor 5, which consisted of the variables of Downward Ingratiation, Downward Exchange, Upward Ingriation, Upward Exchange, Lateral Ingratiation, and Lateral Exchange, which can be interpreted as Leader's Exchange. The tactics of Lateral Rationality, Ingratiation, Exchange, and Upward Ingratiation had the greatest communalities, they accounted for the variance of $88 \%, 79 \%, 77 \%$, and $75 \%$ respectively.

A second order exploratory factor analysis was conducted in order to obtain more general factors. The $5 \times 5$ inter-factor correlations were used for this analysis (see Table IV). A principal components model with the criterion of eigenvalue greater than one, along with a scree plot test, and the common factor model with 
iterated principal axis factoring technique and the criterion of eigenvalue greater than zero all supported a two factor solution. The percentage of total variance accounted for by Factor 1 and Factor 2 before the rotation were $42 \%$ and $15 \%$. The percentages of common variance accounted for were $74 \%$ and $26 \%$. After the rotation, the percentage of total variance accounted for were $32.7 \%$ and $24 \%$; the percentage of common variance accounted for were $57.7 \%$ and $42 \%$. The total variance accounted for by the common factor model was $57 \%$.

The two general factors were orthogonal, and the simple structure was obvious after a Varimax rotation. As seen by inspection of the simple structure in Table VI, General Factor 1 (i.e., which can be called Weak Indirect Tactics Used or Human Relations Oriented Tactics) included variables from the Leader's Rationality, Support Seeking, and Exchange scales; General Factor 2 (i.e., which can be interpreted as Strong Direct Tactics Used or Task-Oriented Tactics) had two high loadings, Leader's Strong Tactics Used Within the Group and Strong Tactics Used Outside the Group. Support Seeking and Strong Tactics Used Outside the Group had the highest communalities, accounting for $74 \%$ and $93 \%$ of the variance respectively.

All the above findings are from descriptive statistics concerning the patterns and general patterns of power tactics used by leaders in organizations. The following statistical discussion regards the testing of hypotheses in the present study.

To test HYPOTHESIS 1, three individual MANOVA analyses were conducted 
corresponding to the downward, the upward, and the lateral influence attempts. The results are shown in Table VII. Although the finding of Kipnis et al. (1980) that leaders at middle level use more Sanctions in downward influence attempts was supported, the hypothesized overall difference in power tactics used by managers and supervisors in downward, upward, and lateral directions was not supported by the multivariate tests. The reason for the nonsignificant results might be due to the vague and indirect measure of management level which simply asked the respondents to rate themselves as to whether they were managers or supervisors.

HYPOTHESIS 2 was supported by the results of multiple regression analysis, as shown in Table VIII.

Size of work unit was significantly and positively related to leader's Downward Sanction, Rationality, Assertiveness; to Lateral Assertiveness, and negatively related to Downward Upward-appeal, and Upward Ingratiation. The findings of Kipnis et al. (1980) that leaders of larger groups use more Assertiveness and Sanctions toward their subordinates were successfully replicated. However, the present findings are distinctly different from the findings of Kipnis et al. (regarding Downward Upward-appeals). Although Kipnis and his colleagues reported that size of work unit was positively related to a leader's ratings on the Upward-appeal scale when the target was a subordinate, they did not find a factor representing Upward-appeals directed toward subordinates in their factor analysis of those questionnaire alone (i.e., they did three separate factor analyses corresponding to 
the three directions of influence attempts). The tactic of Downward Upwardappeal in the present study was negatively related to the measure of the number of employees. In other words, leaders in this study who worked in relatively larger departments were less likely than other leaders to influence their own subordinates by referring the support they had from higher management officials. Additionally, the larger the number of subordinates whom a leader directly supervises, the more Lateral Assertiveness and the less Upward Ingratiation the leader used.

The correlation between the two measures of unit size (number of subordinates v.s. number of employees) was .689 which was significant at the $\mathrm{p}<.01$ level. However, as seen as in Table VIII, the results for number of subordinates are not perfectly consistent with the results for measure of number of employees. Only one of six variables, Downward Rationality, had significant weights in the both measures. The tactics of Downward Sanctions, Downward Rationality, Lateral Assertiveness, and Upward Ingratiation explained about 20\% of the variance in the measure of number of subordinates. The tactics of Downward Rationality, Downward Assertiveness, and Downward Upward-appeal explained about $16.4 \%$ of the variance in the measure of number of employees.

To test HYPOTHESES 3 and 4, a new sample of college students was used. In this sample, half of the subjects received a questionnaire with frequency rating scale anchors and the other half saw questionnaires with an agreement rating scale format. In order to ensure the similarity of the two groups, mean ratings on scores 
of overall job satisfaction from both groups were compared. The results in Table IX showed no significant difference between the comparison groups.

The results shown in Table $\mathrm{X}$ failed to support HYPOTHESIS 3. Partial correlations between the scores on the 5 scales for downward tactics and overall job satisfaction ratings are not significantly different when the two response formats are compared.

When comparing correlations for the agreement and behavioral frequency formats, only the Ingratiation and Rationality scales significantly correlated with job satisfaction. However, the differences between the two formats' correlations with job satisfaction were not significant.

A multivariate analysis with repeated measurements on the tactics scales and the response formats was conducted to test HYPOTHESIS 4. As shown in Table XI, the main effects of Format and Tactics were significant, the interaction between Format and Tactics was not significant. Figure 2 shows the graph of these statistical results. The scale means were based on the scores reported by the subordinates of the group leader's behavior. There was no significant interaction seen between agreement and frequency response formats on the five downward tactics. Therefore, HYPOTHESIS 4 was not supported. 
TABLE II

\begin{abstract}
ALPHA, SCALE MEANS, AND STANDARD DEVIATIONS FOR TACTICS SCALES $(\mathrm{N}=137)$
\end{abstract}

\begin{tabular}{|c|c|c|c|c|c|c|}
\hline \multicolumn{3}{|c|}{ Number of } & \multicolumn{2}{|c|}{ Means } & \multicolumn{2}{|c|}{ Standard Deviations } \\
\hline Tactics & ms & Alpha & Scale & Item & Scale & Item \\
\hline D. Assertiveness & 5 & .895 & 11.45 & 2.29 & 2.41 & .48 \\
\hline D. Rationality & 4 & .890 & 14.18 & 3.55 & 2.45 & .61 \\
\hline D. Ingratiation & 6 & .882 & 15.99 & 2.67 & 3.51 & .59 \\
\hline D. Sanctions & 4 & .893 & 5.27 & 1.32 & 1.84 & .46 \\
\hline D. Exchange & 5 & .885 & 9.10 & 1.82 & 2.58 & .51 \\
\hline D. Upward-appeal & 4 & .889 & 7.75 & 1.94 & 2.42 & .61 \\
\hline D. Blocking & 3 & -- & 3.22 & 1.07 & .56 & .19 \\
\hline D. Coalition & 2 & .890 & 5.57 & 2.79 & 1.83 & .92 \\
\hline U. Assertiveness & 5 & .893 & 7.61 & 1.52 & 2.02 & .40 \\
\hline U. Rationality & 4 & .889 & 16.07 & 4.02 & 2.49 & .62 \\
\hline U. Ingratiation & 6 & .880 & 16.91 & 2.82 & 4.20 & .70 \\
\hline U. Sanctions & 4 & $-\infty$ & 4.13 & 1.03 & .61 & .15 \\
\hline U. Exchange & 5 & .884 & 9.58 & 1.92 & 3.44 & .69 \\
\hline U. Upward-appeal & 4 & .891 & 5.55 & 1.39 & 2.16 & .54 \\
\hline U. Blocking & 3 & -- & 3.27 & 1.09 & .69 & .23 \\
\hline U. Coalition & 2 & .891 & 5.71 & 2.86 & 1.76 & .88 \\
\hline L. Assertiveness & 5 & .892 & 8.99 & 1.80 & 2.28 & .46 \\
\hline L. Rationality & 4 & .886 & 15.22 & 3.81 & 2.34 & .59 \\
\hline L. Ingratiation & 6 & .879 & 17.00 & 2.83 & 4.03 & .67 \\
\hline L. Sanctions & 4 & $-\infty$ & 4.23 & 1.06 & .78 & .20 \\
\hline L. Exchange & 5 & .883 & 11.14 & 2.23 & 3.61 & .72 \\
\hline L. Upward-appeal & 4 & .885 & 7.82 & 1.96 & 2.41 & .60 \\
\hline L. Blocking & 3 & -- & 3.32 & 1.11 & .76 & .25 \\
\hline L. Coalition & 2 & .890 & 5.74 & 2.87 & 1.71 & .86 \\
\hline
\end{tabular}

Note: $\mathrm{D}_{.}=$downward, $\mathrm{U}_{.}=$upward, L.= lateral. 
TABLE III

SCALE INTER-CORRELATIONS ( $\mathrm{N}=137)$

\begin{tabular}{|c|c|c|c|c|c|c|c|c|c|c|c|}
\hline Tactics & 1 & 2 & 3 & 4 & 5 & 6 & 7 & 8 & 9 & 10 & 11 \\
\hline $\begin{array}{l}\text { Downward (1) } \\
\text { Assertiveness } \\
\text { Downward (2) }\end{array}$ & 1 & .06 & .05 & .55 & .17 & .07 & .01 & .33 & .10 & .15 & .18 \\
\hline $\begin{array}{l}\text { Rationality } \\
\text { Downward (3) }\end{array}$ & & 1 & .42 & .14 & .25 & .26 & .40 & .06 & .46 & .35 & .16 \\
\hline $\begin{array}{l}\text { Ingratiation } \\
\text { Downward (4) }\end{array}$ & & & 1 & .03 & .60 & .46 & .41 & .07 & .35 & .66 & .50 \\
\hline $\begin{array}{l}\text { Sanctions } \\
\text { Downward (5) }\end{array}$ & & & & 1 & .19 & .11 & .02 & .17 & .23 & .16 & .21 \\
\hline $\begin{array}{l}\text { Exchange } \\
\text { Downward (6) }\end{array}$ & & & & & 1 & .30 & .25 & .21 & .17 & .49 & .59 \\
\hline $\begin{array}{l}\text { Upward-appeal } \\
\text { Downward (7) }\end{array}$ & & & & & & 1 & .43 & .10 & .18 & .40 & .33 \\
\hline $\begin{array}{l}\text { Coalition } \\
\text { Upward (8) }\end{array}$ & & & & & & & 1 & .12 & .20 & .31 & .27 \\
\hline $\begin{array}{l}\text { Assertiveness } \\
\text { Upward (9) }\end{array}$ & & & & & & & & 1 & .17 & .15 & .32 \\
\hline $\begin{array}{l}\text { Rationality } \\
\text { Upward (10) }\end{array}$ & & & & & & & & & 1 & .42 & .23 \\
\hline $\begin{array}{l}\text { Ingratiation } \\
\text { Upward (11) } \\
\text { Exchange }\end{array}$ & & & & & & & & & & 1 & .61 \\
\hline
\end{tabular}


TABLE III

SCALE INTER-CORRELATIONS ( $\mathrm{N}=137)$

(continued)

\begin{tabular}{|c|c|c|c|c|c|c|c|c|}
\hline tactics & 12 & 13 & 14 & 15 & 16 & 17 & 18 & 19 \\
\hline $\begin{array}{l}\text { Downward (1) } \\
\text { Assertiveness } \\
\text { Downward (2) }\end{array}$ & .10 & .03 & .45 & .12 & .13 & .29 & .19 & .03 \\
\hline $\begin{array}{l}\text { Rationality } \\
\text { Downward (3) }\end{array}$ & .12 & .31 & .10 & .70 & .36 & .18 & .21 & .43 \\
\hline $\begin{array}{l}\text { Ingratiation } \\
\text { Downward (4) }\end{array}$ & .27 & .33 & .14 & .39 & .74 & .51 & .42 & .34 \\
\hline $\begin{array}{l}\text { Sanctions } \\
\text { Downward (5) }\end{array}$ & .03 & .17 & .26 & .28 & .12 & .31 & .34 & .23 \\
\hline $\begin{array}{l}\text { Exchange } \\
\text { Downward (6) }\end{array}$ & .20 & .26 & .29 & .23 & .53 & .65 & .40 & .21 \\
\hline $\begin{array}{l}\text { Upward-appeal } \\
\text { Downward (7) }\end{array}$ & .45 & .30 & .12 & .29 & .30 & .32 & .52 & .31 \\
\hline $\begin{array}{l}\text { Coalition } \\
\text { Upward (8) }\end{array}$ & .25 & .40 & .22 & .40 & .35 & .26 & .23 & .50 \\
\hline $\begin{array}{l}\text { Assertiveness } \\
\text { Upward (9) }\end{array}$ & .29 & .16 & .54 & .16 & .20 & .10 & .30 & .07 \\
\hline $\begin{array}{l}\text { Rationality } \\
\text { Upward (10) }\end{array}$ & .14 & .33 & .09 & .66 & .45 & .27 & .32 & .38 \\
\hline $\begin{array}{l}\text { Ingratiation } \\
\text { Upward (11) }\end{array}$ & .32 & .22 & .19 & .43 & .84 & .64 & .47 & .30 \\
\hline $\begin{array}{l}\text { Exchange } \\
\text { Upward (12) }\end{array}$ & .29 & .16 & .27 & .28 & .55 & .71 & .47 & .19 \\
\hline $\begin{array}{l}\text { Upward-appeal } \\
\text { Upward (13) }\end{array}$ & 1 & .22 & .31 & .26 & .26 & .19 & .40 & .19 \\
\hline $\begin{array}{l}\text { Coalition } \\
\text { Lateral (14) }\end{array}$ & & 1 & .19 & .44 & .24 & .24 & .39 & .62 \\
\hline $\begin{array}{l}\text { Assertiveness } \\
\text { Lateral (15) }\end{array}$ & & & 1 & .23 & .16 & .23 & .38 & .10 \\
\hline $\begin{array}{l}\text { Rationality } \\
\text { Lateral (16) }\end{array}$ & & & & 1 & .45 & .24 & .44 & .57 \\
\hline $\begin{array}{l}\text { Ingratiation } \\
\text { Lateral (17) }\end{array}$ & & & & & 1 & .64 & .49 & .37 \\
\hline $\begin{array}{l}\text { Exchange } \\
\text { Lateral (18) }\end{array}$ & & & & & & 1 & .42 & .20 \\
\hline $\begin{array}{l}\text { Upward-appeal } \\
\text { Lateral (19) } \\
\text { Coalition }\end{array}$ & & & & & & & 1 & .44 \\
\hline
\end{tabular}


TABLE IV

INTER-FACTOR CORRELATIONS

\begin{tabular}{lccccc}
\hline & 1 & 2 & 3 & 4 & 5 \\
\hline Factor 1 & 1.00 & $.40 * \star$ & .17 & .12 & $.20 *$ \\
Factor 2 & & 1.00 & $.23 *$ & $.36 * \star$ & $.42 * *$ \\
Factor 3 & & & 1.00 & $.64 * \star$ & $.46 * \star$ \\
Factor 4 & & & & 1.00 & $.55 * \star$ \\
Factor 5 & & & & & 1.00
\end{tabular}

*<.05

$\star \star<.01$ 
TABLE V

ROTATED FACTOR PATTERN, EIGENVALUES, AND VARIANCES ACCOUNTED FOR

\begin{tabular}{|c|c|c|c|c|c|c|}
\hline actic / Fa & 1 & 2 & 3 & 4 & 5 & $\overline{h^{2}}$ \\
\hline $\begin{array}{l}\text { D.Assertiveness } \\
\text { D. Rationalit } \\
\text { D. Ingratiation } \\
\text { D.Sanctions } \\
\text { D. Exchange } \\
\text { D. Upward-appeal } \\
\text { D. Coalition } \\
\text { U. Assertiveness } \\
\text { U. Rationality } \\
\text { U. Ingratiation } \\
\text { U. Exchange } \\
\text { U. Upward-appeal } \\
\text { U. Coalition } \\
\text { L. Assertiveness } \\
\text { L. Rationality } \\
\text { L. Ingratiation } \\
\text { L. Exchange } \\
\text { L. Upward-appeal } \\
\text { L. Coalition }\end{array}$ & $\begin{array}{r}. .525 \\
-.036 \\
-.195 \\
.803 \\
.083 \\
-.142 \\
-.162 \\
-.043 \\
.071 \\
-.091 \\
.046 \\
-.243 \\
.084 \\
.091 \\
.034 \\
-.123 \\
.299 \\
.092 \\
.130\end{array}$ & $\begin{array}{r}. .312 \\
-.059 \\
-.071 \\
-.050 \\
.025 \\
.108 \\
.074 \\
.759 \\
-.017 \\
.000 \\
.148 \\
.459 \\
.013 \\
.747 \\
.089 \\
-.021 \\
-.165 \\
.246 \\
-.167\end{array}$ & $\begin{array}{r}.025 \\
.639 \\
.084 \\
.041 \\
-.184 \\
-.183 \\
.035 \\
.094 \\
.699 \\
.229 \\
-.142 \\
-.085 \\
.013 \\
-.006 \\
.870 \\
.258 \\
-.205 \\
-.067 \\
.146\end{array}$ & $\begin{array}{r}-.165 \\
.103 \\
.137 \\
.122 \\
.092 \\
.517 \\
. .538 \\
-.134 \\
-.105 \\
-.166 \\
-.038 \\
.065 \\
.734 \\
-.004 \\
.102 \\
-.134 \\
.004 \\
.394 \\
.814 \\
\end{array}$ & $\begin{array}{r}.050 \\
.037 \\
.731 \\
.001 \\
.711 \\
.274 \\
.076 \\
-.058 \\
.124 \\
.846 \\
. .767 \\
.097 \\
-.114 \\
-.053 \\
-.068 \\
.847 \\
.920 \\
. .269 \\
-.125\end{array}$ & $\begin{array}{l}.49 \\
.50 \\
.67 \\
.67 \\
.52 \\
.42 \\
.40 \\
.49 \\
.50 \\
.75 \\
.61 \\
.35 \\
.48 \\
.58 \\
.88 \\
.79 \\
.77 \\
.52 \\
.68\end{array}$ \\
\hline igenvalues & 6.73 & 2.12 & 1.87 & 1.38 & 1.02 & \\
\hline
\end{tabular}

\begin{tabular}{lllllll}
\hline Total Variances & 9.28 & 15.48 & 20.28 & 23.28 & 298
\end{tabular}

\begin{tabular}{lllllll}
\hline Common Variances & $15.7 \%$ & $26.4 \%$ & $34.7 \%$ & $39.9 \%$ & $49.9 \%$
\end{tabular}

Note: $D_{.}=$downward, $\mathrm{U}_{.=}$upward, $\mathrm{L}_{.}=$lateral. 
TABLE VI

ROTATED FACTOR PATTERN, EIGENVALUES, AND VARIANCES ACCOUNTED FOR (THE SECOND ORDER FACTOR ANALYSIS)

\begin{tabular}{|c|c|c|c|}
\hline Tactic Patterns & Factor 1 & Factor 2 & $\overline{h^{2}}$ \\
\hline $\begin{array}{l}\text { Strong Tactic Within Group } \\
\text { Strong Tactic outside Group } \\
\text { Rationality } \\
\text { Support seeking } \\
\text { Exchange }\end{array}$ & $\begin{array}{r}.108 \\
.198 \\
.736 \\
.842 \\
.579 \\
\end{array}$ & $\begin{array}{r}.400 \\
. .943 \\
.109 \\
.185 \\
.327\end{array}$ & $\begin{array}{l}.172 \\
.928 \\
.554 \\
.743 \\
.442\end{array}$ \\
\hline$\overline{e(P C M)}$ & 2.475 & 1.090 & \\
\hline$\overline{\mathrm{e}(\mathrm{CFM})}$ & 1.882 & 0.381 & \\
\hline Total Variances & $32.7 \%$ & $24 \%$ & \\
\hline Common Variances & $57.7 \frac{9}{8}$ & $42 \%$ & \\
\hline
\end{tabular}


TABLE VII

TACTIC SCALE MEANS REPORTED BY MIDDLE MANAGERS VS. LOWER-LEVEL SUPERVISORS ANALYZED BY DIRECTIONS OF INFLUENCE

\begin{tabular}{|c|c|c|c|}
\hline \multicolumn{4}{|c|}{ Downward $(\mathrm{N}=137)$} \\
\hline Tactics & $\begin{array}{c}\text { Managers } \\
(N=65)\end{array}$ & $\begin{array}{c}\text { Supervisors } \\
(N=72)\end{array}$ & $F(1,135)$ \\
\hline $\begin{array}{l}\text { Downward Assertiveness } \\
\text { Downward Rationality } \\
\text { Downward Ingratiation } \\
\text { Downward Sanctions } \\
\text { Downward Exchange } \\
\text { Downward Upward-appeal } \\
\text { Downward Coalition }\end{array}$ & $\begin{array}{r}11.57 \\
14.42 \\
15.89 \\
5.72 \\
8.95 \\
7.52 \\
5.54\end{array}$ & $\begin{array}{r}11.49 \\
14.14 \\
16.04 \\
5.03 \\
9.07 \\
7.43 \\
5.65\end{array}$ & $\begin{array}{l}.04 \text { (ns) } \\
.44 \text { (ns) } \\
.06 \text { (ns) } \\
4.49 * \\
.06 \text { (ns) } \\
.06 \text { (ns) } \\
.13 \text { (ns) }\end{array}$ \\
\hline Wilk's Lambda & & & $.85(\mathrm{~ns})$ \\
\hline
\end{tabular}

\section{Upward $(\mathrm{N}=130)$}

\begin{tabular}{lcrr}
\hline Tactics & $\begin{array}{c}\text { Managers } \\
(\mathrm{N}=64)\end{array}$ & $\begin{array}{c}\text { Supervisors } \\
(\mathrm{N}=66)\end{array}$ & $F(1,128)$ \\
\hline Upward Assertiveness & 7.75 & 7.47 & $.65(\mathrm{~ns})$ \\
Upward Rationality & 16.39 & 16.09 & $.51(\mathrm{~ns})$ \\
Upward Ingratiation & 16.55 & 16.91 & $.26(\mathrm{~ns})$ \\
Upward Exchange & 9.38 & 9.61 & $.17(\mathrm{~ns})$ \\
Upward Upward-appeal & 5.77 & 5.32 & $1.55(\mathrm{~ns})$ \\
Upward Coalition & 5.88 & 5.89 & $.00(\mathrm{~ns})$ \\
Wilk's Lambda & & & $.64(\mathrm{~ns})$ \\
\hline
\end{tabular}




\section{TABLE VII}

TACTIC SCALE MEANS REPORTED BY MIDDLE MANAGERS

VS. LOWER-LEVEL SUPERVISORS ANALYZED BY

DIRECTIONS OF INFLUENCE

(continued)

\section{Lateral $(\mathrm{N}=146)$}

\begin{tabular}{|c|c|c|c|}
\hline Tactics & $\begin{array}{c}\text { Managers } \\
(N=60)\end{array}$ & $\begin{array}{c}\text { Supervisors } \\
(\mathrm{N}=86)\end{array}$ & $F(1,144)$ \\
\hline $\begin{array}{l}\text { Lateral Assertiveness } \\
\text { Lateral Rationality } \\
\text { Lateral Ingratiation } \\
\text { Lateral Exchange } \\
\text { Lateral Upward-appeal } \\
\text { Lateral Coalition }\end{array}$ & $\begin{array}{r}9.33 \\
15.42 \\
16.95 \\
10.93 \\
7.93 \\
5.85\end{array}$ & $\begin{array}{r}9 \cdot 10 \\
15.00 \\
17 \cdot 22 \\
11.14 \\
8.13 \\
5.76\end{array}$ & $\begin{array}{r}.33 \text { (ns) } \\
1.23 \text { (ns) } \\
.17 \text { (ns) } \\
.13 \text { (ns) } \\
.24 \text { (ns) } \\
.12 \text { (ns) }\end{array}$ \\
\hline Wilk's Lambda & & & $.48(\mathrm{~ns})$ \\
\hline
\end{tabular}

$\star<.05$

Note: Managers $=$ middle level leaders; supervisors $=$ lower level leaders. 
TABLE VIII

MULTIPLE REGRESSION ANALYSIS OF POWER TACTICS SCALES PREDICTING TWO UNIT SIZE MEASURES

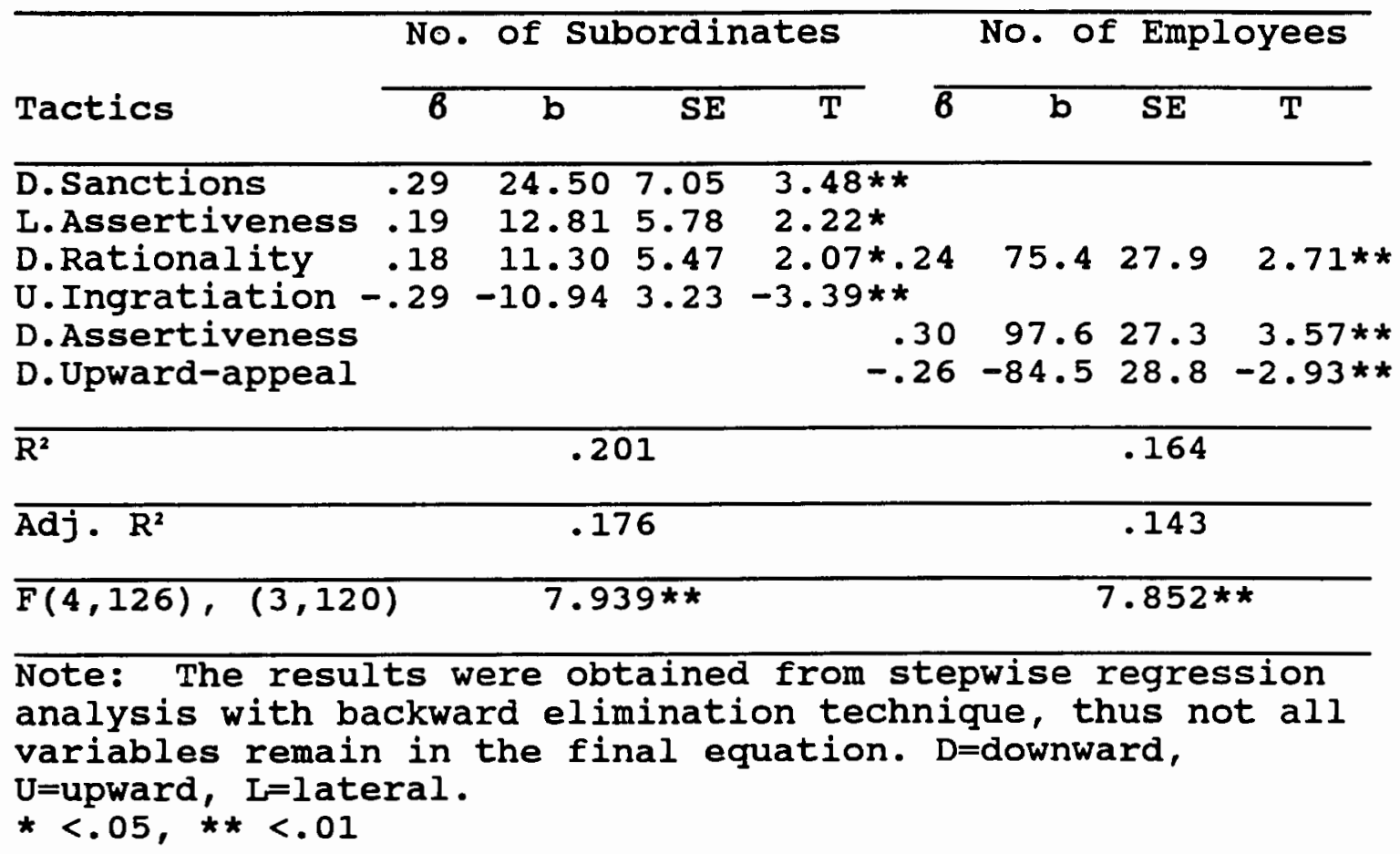


TABLE IX

MEAN JOB SATISFACTION RATING BY POWER

TACTIC SCALE RATING FORMAT

\begin{tabular}{|c|c|c|c|c|}
\hline Rating Formats & $\mathbf{N}$ & Mean & $\begin{array}{l}\text { Standard } \\
\text { Deviation }\end{array}$ & $\begin{array}{c}\text { Standard } \\
\text { Error }\end{array}$ \\
\hline $\begin{array}{l}\text { Agreement } \\
\text { Frequency }\end{array}$ & $\begin{array}{l}70 \\
70\end{array}$ & $\begin{array}{l}74.69 \\
73.67\end{array}$ & $\begin{array}{l}14.44 \\
12.38\end{array}$ & $\begin{array}{l}1.73 \\
1.48\end{array}$ \\
\hline
\end{tabular}


TABLE X

SECOND-ORDER CORRELATIONS BETWEEN TACTICS USED AND OVERALL JOB SATISFACTION $(\mathrm{N}=70)$

BY RATING SCALE FORMAT

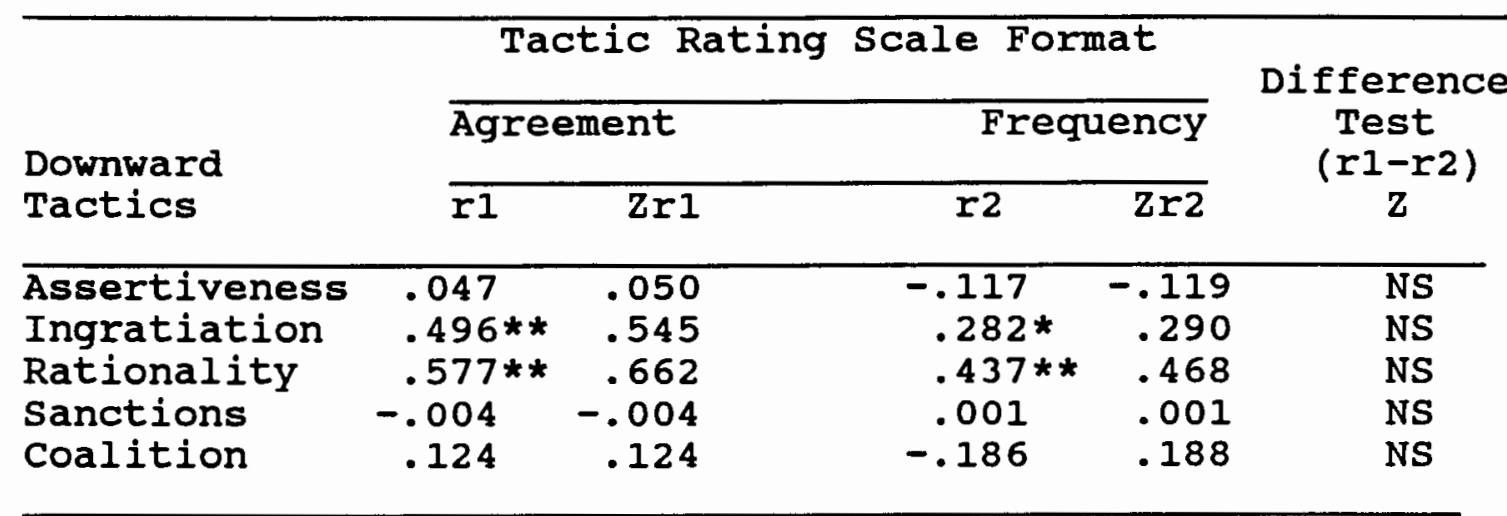

$\star<.05$

$\star *<.01$ 
TABLE XI

MULTIVARIATE ANALYSIS OF THE DIFFERENCES BETWEEN AGREEMENT FORMAT AND FREQUENCY FORMAT WITH TACTIC SCALES AS REPEATED MEASUREMENTS

$$
(N=140)
$$

\begin{tabular}{lcr}
\hline Sources & Degree of Freedom & Wilk's Lambda F \\
\hline Format & 5 & $4.2376 * \star \star$ \\
Tactics & 4 & $349.1131 * \star \star$ \\
Format X Tactics & 4 & 1.1083 \\
& &
\end{tabular}




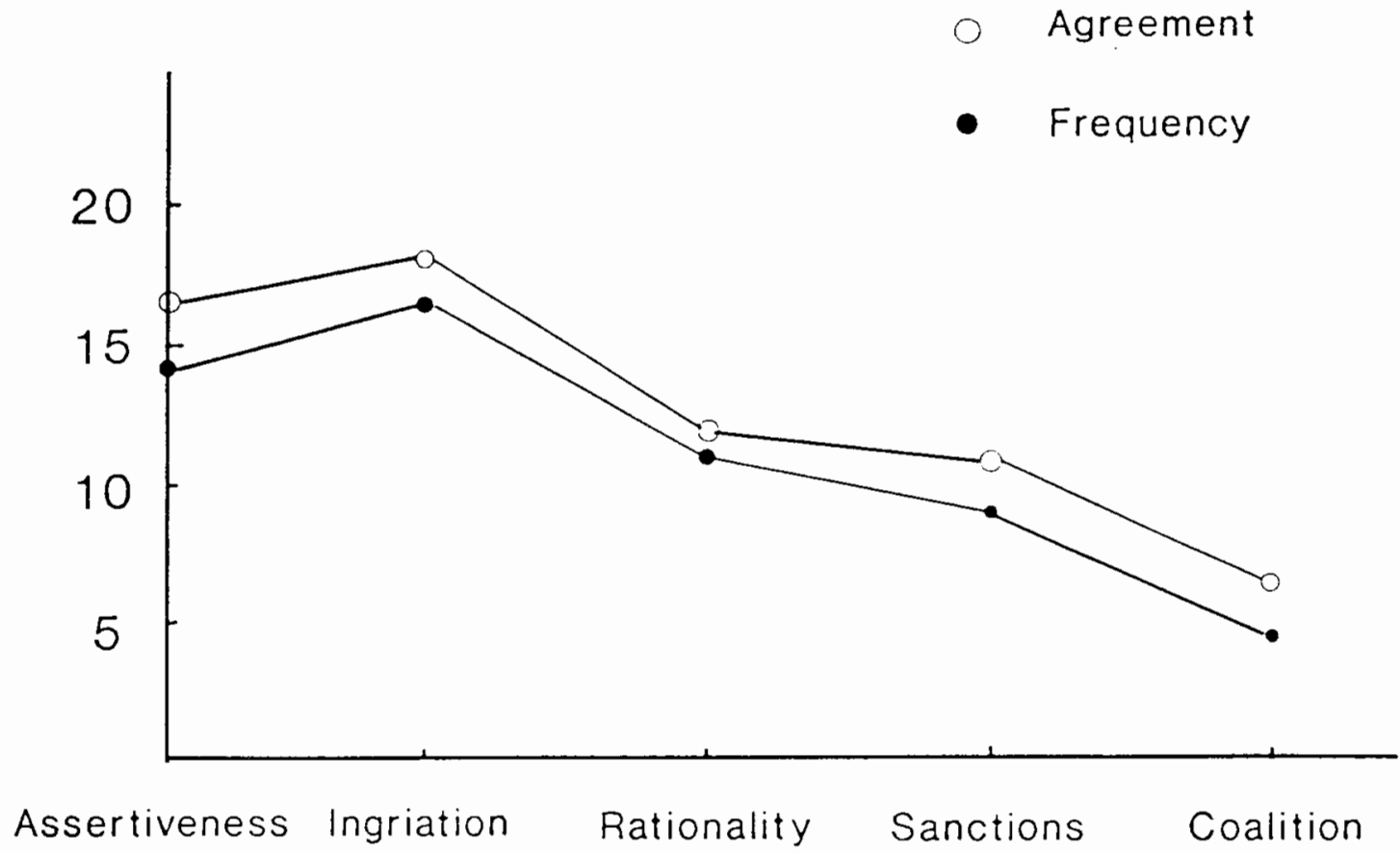

Figure 2. Comparison of Scale Means between Agreement Format and Frequency Format. 


\section{DISCUSSION}

Kipnis et al. (1980) found that there were eight factors or tactics in managerial power use from their overall factor analysis. The eight factors in the present study were assumed to be true in all three directions for influence attempts. However, the sample of this study was taken from U.S. West Communications Inc. and eight other organizations in the northwest region. Leaders in the present sample who do not use the tactic of Blocking might be constrained by the organizational culture of these specific companies in this specific region. The items on the Blocking scale consist of threatening "to notify an outside agency if he or she did not give in to my request," "to stop working with him or her until he or she gave in," and engaging in "a slowdown until he or she did what I wanted." All these questions are negative managerial behavior, so they might not have been reported by the respondents who were also full-time organizational leaders. Even if Blocking does factually exist, the way that leaders see themselves is different from the way that others see leaders in terms of power tactics use in organizations (Frost, 1992). Furthermore, items on the Sanctions scale asked whether or not a salary increase was given or negative performance evaluations were given to target persons. The respondents reported that they never used Sanctions as a power tactic toward their superiors and peers, which might be due to the organizational culture, their lack of authority, or the both. This finding is different from the decisions made by 
Yukl and Falbe (1990). First of all they deleted Blocking and Sanctions based on their conceptual reasons, in this study these two scales were excluded only because the empirical findings showed that they had minimal variances. Moreover, they deleted Blocking and Sanctions for all possible targets whereas in this study the tactic of Sanctions in downward influence attempts was retained because empirical results showed that leaders do use Sanctions directed towards their subordinates.

\section{POWER TACTIC USE PATTERNS AND GENERAL STRATEGIES}

The factor analysis based on the findings of Kipnis et al. (1980) overall analysis and the multidirectional assumption of the existence of the 8 tactics resulted in 5 common tactics use patterns.

\section{Strong Tactics Within Group}

Leaders who score highly on this factor tend to control their subordinates by using the tactics of Assertiveness and Sanctions. For example, they demand their subordinates to do what is requested, bawl the subordinates out, give them no salary increase or prevent them from getting a pay raise, threaten to give them unsatisfactory performance evaluations and so on.

\section{Strong Tactics Outside Group}

Leaders who score highly on this factor tend to use the tactics of Assertiveness towards their superiors and peers, and Upward-appeal to their superiors. For example, leaders demand their superiors and peers do what they request, set time 
deadlines for them to do what is asked, make formal appeals to their superiors' boss to back up requests, obtain the informal support of the superiors' boss, and sometimes file reports about their superiors with the superiors' boss.

\section{$\underline{\text { Rationality }}$}

Leaders who have high scores on this factor use logic to convince others, including their subordinates, superiors and peers. They often write detailed plans to justify their ideas, present information in support of their point of view, and explain the reasons for their requests.

\section{Support Seeking}

Some leaders attempt to obtain the support from their subordinates, peers, and superiors to back up their requests. They also try to obtain formal or informal support from their peers' superiors. Sometimes they send to their superiors those subordinates and peers who do not do what has been requested.

\section{Exchange}

Leaders who score highly on this factor act in a friendly manner prior to asking for what they want, make their subordinates, peers, and superiors feel good about them before making their requests. Those leaders act humbly to their subordinates, peers, and superiors while making their requests, sometimes they wait until the target persons appear in a receptive mood before asking, and they often express their sympathy about the added problems that the request has caused. These leaders often offer exchanges for what their subordinates, superiors, 
and peers do for them, they offer to make personal sacrifices if the target persons do what are asked. Sometimes they remind the target persons that they did personal favors for them in order to get something in return.

In order to obtain general power use strategies by leaders in organizations, a second order factor analysis shows that two general power use strategies exist.

\section{Weak Indirect Tactics (or Human Relations Tactics)}

Leaders who belong to this general category use the tactics of Rationality, Ingratiation, Exchange to, and seek support from their subordinates, peers, and superiors. They also try to seek out formal or informal support from their peers' superiors. In this general strategy, Support seeking is most important, and Exchange is least important in defining the strategy.

\section{Strong Direct Tactics (or Task-Oriented Tactics)}

Leaders in this category often try to control their subordinates, use Strong Tactics Outside their direct group, such as demanding their superiors and peers to do what they request, and filing reports about their superiors with their superiors' supervisors. In this general strategy, Strong Tactics Outside Group is the central pattern.

These two general power use strategies are consistent with results of the Ohio State Leadership Studies (Fleishman, 1953; Halpin \& Winer, 1957; Hemphill \& Coons, 1957). Weak Indirect Tactics and Strong Direct Tactics are very much like Consideration and Initiating Structure in the leadership theory. The key difference 
is that the Ohio State Leadership Studies examined only the leader-subordinate relationship, and the present study is about the multidimensionality of leader's power use. Looking at the leader's behavior with peers and superiors as well as with subordinates is the major contribution of this study.

Recently, Kipnis (1992) used the Petty and Cacioppo concepts of central versus peripheral tactics to explain behavioral technology used by leaders. Using central route tactics fosters the belief that target persons have made-up their own minds; using peripheral route tactics fosters the belief that target persons' minds were made-up for them. In other words, leaders who use central route influence tactics believe that target persons are responsible for their own behavior changes; leaders who use peripheral route influence tactics assume that target persons are simple-minded, and are not responsible for the changes of their own behaviors.

According to Kipnis (1992), the central route of influence includes the tactics of discussion, rational arguements, and democratic choices; the peripheral route includes the tactics of door in face, reinforcements, and so on. In this sense, the two general power use strategies found in this study are very similar with the two route of influence techniques. The strategy of Weak Indirect Tactics is like the central route of influence; and the strategy of Strong Direct Tactics resembles the peripheral route of influence. 


\section{MANAGEMENT HIERARCHY EFFECTS ON POWER TACTICS USE}

Previous theories and prior research suggests that a leader's level in an organization's authority hierarchy is closely associated with the use of influence tactics. Sanctions applied to subordinates were found in this study to be used more by managers than by supervisors, which is consistent with Kipnis et al.'s findings (1980). However, overall differences between managers and supervisors in all three directions in terms of power tactics used were not found in this study. The reason for that might be a managerial response bias. The perception that leaders hold about themselves in terms of power use differs from the perception that subordinates hold about their leaders (Frost, 1992). Previous theories and research concerning the relationship between management level and power tactics used were mostly based on the responses from subordinates or college students, while the respondents in the present study were all full-time organizational leaders. The another reason might be the confusion about the definition of the management level. For example, some leaders in the present study considered themselves as managers but they only had several subordinates, others considered themselves as supervisors with several dozen of subordinates. This confusion might have affected the leaders' responses when they were asked to rate themselves managers or supervisors.

In order to examine the effect of management level on power tactics use, a clearer and more objective measure of management level should be used. A representative from the personnel department could be involved in rating the 
respondents' level of management, for example. The number of subordinates whom a leader directly supervises might be a good indicator because a higher level leader usually has more subordinates than a lower level leader.

In this study, a leader of more subordinates uses more Rationality, Sanctions toward his/her subordinates, more Assertiveness toward his/her peers, and less Ingratiation toward his/her superiors than a leader of fewer subordinates. A leader of more employees in his/her department uses more Assertiveness, Rationality, and less Upward-appeal toward his/her subordinates than a leader of fewer employees in his/her department. Perhaps the more subordinates a leader has, the higher level the leader is in the organizational hierarchy. In this sense, the findings of Kipnis et al. that higher level leaders use more Rationality and Assertiveness in both downward and upward directions, Sanctions and Upward-appeals in downward influence attempt are partially supported.

\section{WORK UNIT SIZE AND POWER TACTICS USE}

Although two different measures of work unit size were used in the present study, the findings of Kipnis et al.(1980) that leaders of larger groups use more Assertiveness, and Sanctions toward their subordinates are strongly supported. However, the present findings showed that leaders of larger groups use less Upward-appeal tactics with their subordinates, which was opposite to the findings of Kipnis et al. The Kipnis et al. study found that leaders of larger groups used more Upward-appeals with their subordinates. The tactic of Upward-appeal 
toward subordinates in this study was only related to the number of employees whom the leaders work directly with. Perhaps in this specific sample, the more employees whom leaders work with in their units, the more reluctantly they show their incapability of directly dealing with problem subordinates. In other words, leaders who work with large number of employees in their work units try to make every efforts to deal with problem subordinates themselves instead of referring them to the superiors.

The present findings are also consistent with the findings of Stahelski, Frost and Patch (1989) that an increase of group size is positively related to the increase of leaders' coercive power use. Moreover, leaders' lateral and upward power tactics use are related only to the measure of number of subordinates whom the leaders directly supervise, not to the number of employees whom the leaders work with. These two measures of work unit size as suggested by Yukl (1989) were used for the first time in this study to analyze the multidimensionality of power use in organizations. The current findings can be considered a major contribution to the field of organizational research.

\section{RESPONSE FORMATS OF POWER TACTICS USE MEASURE}

In terms of the response formats of the survey questionnaire, the Kipnis et al. behavioral frequency format (1980) versus Hinkin and Schriesheim agreement format (1989), no significant difference was found in terms of correlating both formats with the Minnesota Overall Job Satisfaction scales. The results suggest 
that the argument made by Podsakoff and Schrieshem (1985) that the behavioral frequency format makes the scales more valid than the agreement format is not supported; both response formats seem valid in power tactics research. Although the agreement format is biased by respondents' subjective perception, the frequency format may be contaminated by memory recall error or selective recall. The response scales of the both formats are based on self-reports, which are subject to respondents' social desirability and other subjective biases.

\section{THE IMPLICATIONS OF THE STUDY}

The findings of the present study demonstrate the complexity of power use in organizations. The important implications of the present study are: (1) researchers need to more thoroughly understand the complex multidimensional power relations in organizations; (2) organizational leaders need to understand what the most common patterns of tactics use and general power use strategies are to influence their subordinates, superiors, and peers so that they can use them wisely to obtain necessary resources and support for their task accomplishment; (3) organizational leaders need to recognize the situational constraints on power tactics used, such as the constrains of management level and work unit size; (4) and finally these results may help organizations to design management training and development programs in order to gain profit maximization. 


\section{THE CONTRIBUTIONS OF THE STUDY}

There are some important contributions that this study has made to leadership research: First, it is the first study to examine power tactic use patterns multidimensionally, including the two general tactics use strategies which once again confirm Ohio State Leadership Scales. Second, it is the first study to use two different measures of unit size to study the relationship between unit size and power tactics use. Third, it has also examined the relationship between work unit size and upward and lateral power tactics use for the first time. Finally, it has settled the argument empirically about whether or not the behavioral frequency response format is superior to the traditional agreement response format (e.g., Podsakoff \& Schrieshem in 1985).

\section{RECOMMENDATIONS FOR FUTURE RESEARCH}

Future research should focus on confirming the power tactic patterns found in the present study and testing causality among the patterns or between the patterns and other indicators if possible. Future research should also test the relationship between power tactic patterns and criterion measures (such as productivity of a leader's work unit, performance evaluation, satisfaction, turnover, and so on), so that the effectiveness of tactic use pattern(s) can be examined and predicted. Additionally, future research should attempt to develop more objective and direct measures of management levels and test their relationship to power tactics used multidimensionally. Instead of arguing which response format of survey 
questionnaire to use, future study may need to pay more attention to other techniques in collecting data, such as field observation, to reduce subjective response biases. 


\section{REFERENCES}

Allen, Robert W., \& Porter, Lyman W. (1983) (Eds.). Organizational Influence Processes. Glenview, IL: Scott, Foresman and Company.

Bachman, J. G. (1968). Faculty Satisfaction and the Dean's Influence: An Organizational Study of Liberal Arts Colleges. Journal of Applied Psychology, 52, 55-61.

Bachman, J. G., Bowers, D. G., \& Marcus, P. M. (1968). Bases of Supervisory Power: A Comparative study in Five Organizational Settings. In A. S. Tannenbaum (Ed.), Control in Organizations (pp. 213-227). New York: McGraw-Hill.

Bachman, J. G., Smith, C. B., \& Slesinger, J. A. (1966). Control, Performance and Satisfaction: An Analysis of Structural and Individual Effects. Journal of Personality and Social Psychology, 4, 127-136.

Bass, Bernard M. (1990). Stogdill's Handbook of Leadership: Theory, Research, and Managerial Applications (3rd ed.). New York: Free Press.

Bennett, Joel B. (1988). Power and Influence as Distinct Personality Traits:

Development and Validation of a Psychometric Measure. Journal of Research in Personality, 22, 361-394.

Blankenship, L. Vaughn, \& Miles, Raymond E. (1968). Organizational Structure and Managerial Decision Behavior. Administrative Science Quarterly, 13, 106-120.

Burke, R. J., \& Wilcox, D. S. (1971). Bases of Supervisory Power and Subordinate Job Satisfaction. Canadian Journal of Behavioral Science, 3 , 183-193.

Busch, P. (1980). The Sales Manager's Bases of Social Power and Influence upon the Salesforce. Journal of Marketing, 44, 91-101.

Cashman, James, Dansereau, Fred Jr., Graen, George, \& Haga, William J. (1976). Organizational Understructure and Leadership: A Longitudinal Investigation of the Managerial Role-Making Process. Organizational Behavior and Human Performance, 15, 278-296. 
Collins, Barry E., \& Raven, Bertram H. (1969). Group Structure: Attraction, Coalitions, Communication, and Power. In G. Lindzey \& E. Aronson (Eds.), The Handbook of Social Psychology (Vol. 4, pp. 102-204). Reading, MA: Addison-Wesley Publishing Company.

Cope, R. G. (1972). Bases of Power, Administrative Preferences and Job Satisfaction: A Situational Approach. Journal of Vocational Behavior, $\underline{2}$, 457465.

Dunne, Edward J., Jr., Stahl, Michael J., \& Melhart, Leonard J., Jr. (1978). Influence Sources of Project and Functional Managers in Matrix Organizations. Academy of Management Journal, 21, 135-140.

Enz, Cathy A. (1988). The Role of Value Congruity in Intraorganizational Power. Administrative Science Quarterly, 33, 284-304.

Falbo, Toni (1977). Multidimensional Scaling of Power Strategies. Journal of Personality and Social Psychology, 35, 537-547.

Ford, Jeffrey D. (1981). Departmental Context and Formal Structure as Constraints on Leader Behavior. Academy of Management Journal, 24, 274288.

French, J., \& Raven, B. H. (1959). The Bases of Social Power. In D. Cartwright (Ed.), Studies in Social Power (pp. 150-167). Ann Arbor, MI: Institute for Social Research.

Frost, Dean E. (1992). Behavioral Frequency Reports of Social Power in a Field Setting: Correlation of Agent, Target, and Third Party Ratings. Paper Presented at the Meetings of the Western Psychological Association, Portland, Oregon, May.

Frost, Dean E., \& Staheiski, Anthony J. (1988). The Systematic Measurement of French and Raven's Bases of Social Power in Workgroups. Journal of Applied Social Psychology, 18, 375-389.

Goodstadt, Barry, \& Kipnis, David (1970). Situational Influences on the Use of Power. Journal of Applied Psychology, 54, 201-207.

Graen, George, Cashman, James F., Ginsburg, Steven, \& Schiemann, William (1977). Effects of Linking-Pin Quality on the Quality of Working Life of Lower Participants. Administrative Science Quarterly, 22, 491-504. 
Green, S. E., \& Liden, R: C. (1980). Contextual and Attributional Influences on Control Decisions. Journal of Applied Psychology, 65, 453-458.

Hammer, Tove H., \& Turk, Jay M. (1987). Organizational Determinants of Leader Behavior and Authority. Journal of Applied Psychology, 72, 674-682.

Hinkin, Timothy R., \& Schriesheim, Chester A. (1989). Development and Application of New Scales to Measure the French and Raven (1959) Bases of Social Power. Journal of Applied Psychology, 74, 561-567.

Hollander, Edwin P., \& Offermann, Lynn R. (1990). Power and Leadership in Organizations: Relationships in Transition. American Psychologist, $45,179-$ 189.

Isenberg, Daniel J. (1984). How Senior Managers Think? Harvard Business Review, November-December, 81-90.

Ivancevich, John M. (1970). An Analysis of Control, Bases of Control, and Satisfaction in an Organizational Setting. Academy of Management Journal, 13, 423-437.

Ivancevich, J. M., \& Donnelly, J. H. (1970). Leader Influence and Performance. Personnel Psychology, 23, 539-549.

Kanter, Rosabeth Moss (1982). The Middle Manager as Innovator. Harvard Business Review, July-August, 95-105.

Kaplan, Robert E. (1984). Trade Routes: The Manager's Network of Relationships. Organizational Dynamics, Spring, 37-52.

Kipnis, David (1992). Applying Newton's Second Law to Behavioral Technology. Paper Presented at the Meetings of the Western Psychological Association, Portland, Oregon, May.

Kipnis, David, \& Cosentino, Joseph (1969). Use of leadership Power in Industry. Journal of Applied Psychology, 53, 460-466.

Kipnis, David, \& Lane, William P. (1962). Self-Confidence and Leadership. Journal of Applied Psychology, 46, 291-295.

Kipnis, David, \& Schmidt, Stuart M. (1983). An Infuence Perspective on Bargaining within Organizations. In M. H. Bazerman \& R. J. Lewicki (Eds.), Negotiating in Organizations (pp. 303-319). Beverly Hill, CA: Sage Publications, Inc.. 
Kipnis, D., Schmidt, S. M., \& Wilkinson, I. (1980). Intra-organizational Influence Tactics: Explorations in Getting One's Way. Journal of Applied Psychology, 65, 440-452.

Landsberger, Henry A. (1961). The Horizontal Dimension in Bureaucracy. Administrative Science Quarterly, 6, 299-332.

Locke, E. A. (1976). The Nature and Causes of Job Satisfaction. In M. D. Dunnette (Ed.), Handbook of Industrial and Organizational Psychology (pp. 189-195). Chicago: Rand McNally.

Martin, T. N., \& Hunt, J. G. (1980). Social Influence and Intent to Leave: A Path-Analytic Process Model. Personnel Psychology, 33, 505-528.

McClelland, David G., \& Burnham, David H. (1976). Power as Motivator. Harvard Business Review, March-April, 100-110.

Mechanic, David (1962). Sources of Power of Lower Participants in Complex Organizations. In R. W. Allen \& L. W. Porter (Eds.), Organizational Influence Process (pp. 348-360). Glenview, IL: Scott, Foresman and Company.

Mintzberg, Henry (1979). The Structuring of Organizations. Englewood Cliffs, NJ: Prentice-Hall, Inc..

Nystrom, Paul C. (1990). Vertical Exchanges and Organizational Commitments of American Business Managers. Group and Organization Studies, 15, 296-312.

O'Reilly, C. A., III. (1989). Corporations, Culture, and Commitment: Motivation and Social Control in Organizations. California Management Review, 31, 9-25.

Osborn, R. N. (1971). Organizational Effectiveness: A Model and a Test. Unpublished Dissertation, Kent State University.

Osborn, Richard N., \& Hunt, James G. (1974). Leadership at Two Organizational Levels. Journal of Business Research, 2, 209-221.

Pelz, Donald C. (1952). Influence: A Key to Effective Leadership in the FirstLine Supervisor. Personnel, 29, 3-11.

Pfeffer, Jeffrey (1981). Power in Organizations. Cambridge, MA: Ballinger Publishing Company. 
Pfeffer, Jeffrey, \& Salancik, Gerald (1975). Determinants of Supervisory Behavior: A Role Set Analysis. Human Relations, 28, 139-154.

Podsakoff, Philip M. (1982). Determinants of a Supervisor's Use of Rewards and Punishments: A Literature Review and Suggestions for Further Research. Organizational Behavior and Human Performance, 29, 58-83.

Podsakoff, Philip M., \& Schriesheim, Chester A. (1985). Field Studies of French and Raven's Bases of Power: Critique, Reanalysis, and Suggestions for Future Research. Psychological Bulletin, 97, 387-411.

Podsakoff, Philip M., Todor, William D., Grover, Richard A., \& Huber, Vandra L. (1984). Situational Moderators of Leader Reward and Punishment Behaviors: Fact or Fiction? Organizational Behavior and Human Performance, 34, 21-63.

Rahim, M. Afzalur (1989). Relationships of Leader Power to Compliance and Satisfaction with Supervision: Evidence from a National Sample of Managers. Journal of Management, 15, 545-556.

Sayles, Leonard R. (1979). Leadership: What Effective Managers Really Do ... and How They Do It. New York: McGraw-Hill Book Company.

Sayles, Leonard (1964). Managerial Behavior. New York: McGraw-Hill.

Sheridan, J. E., \& Vredenburgh, D. J. (1978). Usefulness of Leadership Behavior and Social Power Variables in Predicting Job Tension, Performance, and Turnover of Nursing Employees. Journal of Applied Psychology, 63, 89-95.

Singer, Ming S., \& Singer, Alan E. (1990). Situational Constraints on Transformational Versus Transactional Leadership Behavior, Subordinates' Leadership Preference, and Satisfaction. The Journal of Social Psychology, 13, 385-396.

Singh, Chandra B. P. (1988). Behavioural Strategies for Influencing Immediate superiors. Psychologia, $31,34-41$.

Slocum, J. W., Jr. (1970). Supervisory Influence and the Professional Employee. Personnel Journal, 49, 484-488.

Stahelski, Anthony J., Frost, Dean E., \& Patch, Michael E. (1989). Use of Socially Dependent Bases of Power: French and Raven's Theory Applied to Workgroup Leadership. Journal of Applied Social Psychology, 19, 283-297. 
Student, K. R. (1968). Supervisory Influence and Workgroup Performance. Journal of Applied Psychology, 52, 188-194.

Thamhain, H. J., \& Gemmill, G. R. (1974). Influence Styles of Project Managers: Some Project Performance Correlates. Academy of Management Journal, 17, 216-224.

Warren, Donald I. (1968). Power, Visibility, and Conformity in Formal Organizations. American Sociological Review, 33, 951-970.

Yamagishi, Toshio, Gillmore, Mary R., \& Cook, Karen S. (1988). Network Connections and the Distribution of Power in Exchange Networks. American Journal of Sociology, 93, 833-851.

Yukl, Gary A. (1989). Leadership in Organizations (2nd ed.). Englewood Cliffs, NJ: Prentice-Hall, Inc..

Yukl, Gary A., \& Falbe, Cecilia (1991). Importance of Different Power Sources in Downward and Lateral Relations. Journal of Applied Psychology, 76, 416423.

Yukl, Gary A., \& Falbe, Cecilia M. (1990). Influence Tactics and Objectives in Upward, Downward, and Lateral Influence Attempts. Journal of Applied Psychology, 75, 132-140.

Zald, Mayer N. (1970) (Ed.). Power in Organizations. Nashville, Tennessee: Vanderbilt University Press. 
APPENDIX A

KIPNIS ET AL. ORIGINAL QUESTIONNAIRE 


\section{APPENDIX A}

\section{KIPNIS ET AL. ORIGINAL QUESTIONNAIRE}

INSTRUCTIONS: Below is a questionnaire of how managers direct and influence behaviors of their subordinates, superiors, and peers at work. Please respond how often you use these behaviors by circling the appropriate number indicating use of that behavior in working with subordinates, superiors, and peers on the job. Do not answer interms of what you would like to do, or what should be done. If a particular behavior does not apply to your job leave that space blank.

$$
\begin{aligned}
& 1=\text { Never } \\
& 2=\text { Seldom } \\
& 3=\text { Occasionally } \\
& 4=\text { Frequently } \\
& 5=\text { Usually }
\end{aligned}
$$

\section{ASSERTIVENESS}

45. Simply ordered him or her to do what was asked.

18. Demanded that he or she do what I requested.

39. Bawled him or her out.

11. Set a time deadline for him or her to do what I asked.

19. Told him or her that the work must be done as ordered or he or she should propose a better way.

\section{INGRATIATION}

46. Made him or her feel important ("only you have the brains, talent to do this").

9. Acted very humbly to him or her while making my request.

17. Acted in a friendly manner prior to asking for what I wanted.

28. Made him or her feel good about me before making my request.

3. Sympathized with him/her about the added problems that my request has caused.

44. Waited until he or she appeared in a receptive mood before asking.

\section{RATIONALITY}

40. Wrote a detailed plan that justified my ideas.

38. Presented him or her with information in support of my point of view.

31. Explained the reasons for my request.

13. Used logic to convince him or her. 


\section{SANCTIONS}

49. Gave no salary increase or prevented the person from getting a pay raise.

15. Promised (or gave) a salary increase.

6. Threatened to give him or her an unsatisfactory performance evaluation.

34. Threatened him or her with loss of promotion.

\section{EXCHANGE}

35. Offered an exchange (e.g., if you do this for me, I will do something for you).

27. Reminded him or her of past favors that I did for them.

50. Offered to make a personal sacrifice if he or she would do what I wanted (e.g., work late, work harder, do his/her share of the work, etc).

55. Did personal favors for him or her.

7. Offered to help if he/she would do what I wanted.

UPWARD APPEAL

58. Made a formal appeal to higher levels to back up my request.

20. Obtained the informal support of higher-ups.

25. Filed a report about the other person with higherups (e.g., my superior).

33. Sent him or her to my superior.

\section{BLOCKING}

47. Threatened to notify an outside agency if he or she did not give in to my request.

48. Threatened to stop working with him or her until he or she gave in.

4. Engaged in a work slowdown until he or she did what I wanted.

\section{COALITIONS}

12. Obtained the support of co-workers to back up my request.

32. Obtained the support of my subordinates to back up my request. 


\section{APPENDIX B}

TWO FORMS OF POWER USE QUESTIONNAIRE 
APPENDIX B

TWO FORMS OF POWER USE QUESTIONNAIRE

Form A

\section{DIRECTIONS}

I am conducting research on how managers direct and influence behavior of their subordinates. As a starting point, I am attempting to operationally define and measure specific work behaviors used to influence coworker's actions. I am only interested in how supervisors use these behaviors and ask you to please respond by circling the appropriate number to describe how your supervisor directs your workgroup. Your survey will not be seen by anyone but myself and your responses will be confidential, anonymous, and reported in grouped form only. I hope you will now share with me how frequently you see your supervisor using the following behaviors in directing subordinates' work activities. Please feel free to contact me if you have any questions about this study. Thank you for your assistance.

$$
\begin{aligned}
& 5=\text { almost always } \\
& 4=\text { often } \\
& 3=\text { occasionally } \\
& 2=\text { seldom } \\
& 1=\text { never }
\end{aligned}
$$

HOW OFTEN DOES THE SUPERVISOR USE THIS BEHAVIOR TO INFLUENCE SUBORDINATES?

1. Promotes them or recommends them for $\begin{array}{lllllll}1 & 2 & 3 & 4 & 5\end{array}$ promotion.

2. Demotes them or recommends for promotion.1 $2 \begin{array}{lllll}3 & 4 & 5\end{array}$

3. Advises and assists them. $\quad \begin{array}{lllllll} & 2 & 3 & 4 & 5\end{array}$

4. Sets the example and relies upon them $1 \quad \begin{array}{llllll}2 & 3 & 4 & 5\end{array}$ to follow his/her example.

5. Expects that his/her orders and requests $1 \quad 2 \quad \begin{array}{lllll}3 & 4 & 5\end{array}$ will be carried out because he/she is the boss and they will not question an order from a superior. 
6. Recommends them for awards or for

$\begin{array}{lllll}1 & 2 & 3 & 4 & 5\end{array}$

announcements of recognition.

7. Makes on-the-spot corrections.

$\begin{array}{lllll}1 & 2 & 3 & 4 & 5\end{array}$

8. Uses his/her good relationship with them to get the job done.

$\begin{array}{lllll}1 & 2 & 3 & 4 & 5\end{array}$

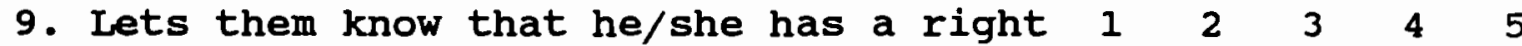

to expect that his/her directions will

be followed.

10. Gives them high performance ratings. $\begin{array}{lllllll}1 & 2 & 3 & 4 & 5\end{array}$

11. Gives them low performance ratings. $\begin{array}{llllll}1 & 2 & 3 & 4 & 5\end{array}$

12. Gives them interesting, challenging $\begin{array}{lllllll}1 & 2 & 3 & 4 & 5\end{array}$

assignments.

13. Relies upon them to get the job done $\begin{array}{lllllll}1 & 2 & 3 & 4 & 5\end{array}$ because they don't want to let him/her down.

14. Emphasizes that he/she probably has $1102 \quad 3 \quad 4 \quad 5$ information that they do not have and

therefore a good reason for any direct

request or order.

15. Praises them.

$\begin{array}{lllll}1 & 2 & 3 & 4 & 5\end{array}$

16. Criticizes them.

$\begin{array}{lllll}1 & 2 & 3 & 4 & 5\end{array}$

17.Gives them boring, routine assignments. $\begin{array}{llllll}1 & 2 & 3 & 4 & 5\end{array}$

18. Counts on them to believe that it is to $1 \quad 2 \quad \begin{array}{llllll} & 3 & 4 & 5\end{array}$ their advantage as much as it is to his/hers for them to cooperate with him/her.

19. Gives them extra time off as a reward. $\begin{array}{llllll}1 & 2 & 3 & 4 & 5\end{array}$ 20. Gives them extra work as punishment. $\begin{array}{lllllll}1 & 2 & 3 & 4 & 5\end{array}$

21. Gets them to accomplish the work by $\begin{array}{lllllll}1 & 2 & 3 & 4 & 5\end{array}$ demonstrating that he/she knows how to perform the task.

22. Recommends them for formal disciplinary $11 \begin{array}{lllll}2 & 3 & 4 & 5\end{array}$ action or reprimands.

23. Impresses them with his/her overall $1123 \quad 3 \quad 4 \quad 5$ competence and ability. 


$$
\begin{aligned}
& 5=\text { almost always } \\
& 4=\text { often } \\
& 3=\text { occasionally } \\
& 2=\text { seldom } \\
& 1=\text { never }
\end{aligned}
$$

24.Simply orders them to do what is asked. $\begin{array}{llllll}1 & 2 & 3 & 4 & 5\end{array}$ 25. Demands that they do what he requests. $\begin{array}{llllll}1 & 2 & 3 & 4 & 5\end{array}$

26. Bawls them out.

27. Sets a time deadline for them to do what he/she asks.

28. Tells them that the work must be done 1 as ordered or they should propose a better way.

29. Makes them feel important ("only you have the brains, talent to this").

$\begin{array}{llllllll}30 & \text { Acts very humbly to them while making } & 1 & 2 & 3 & 4 & 5\end{array}$ his/her request.

31. Acts in a friendly manner prior to asking for what he/she wants.

32. Makes them feel good about him/her before making his/her request.

33. Sympathizes with them about the added $1120 \begin{array}{lllll}1 & 2 & 3 & 4 & 5\end{array}$ problems that his/her request has caused.

34. Waits until they appear in a receptive $\begin{array}{llllll}1 & 2 & 3 & 4 & 5\end{array}$ mood before asking.

35. Writes a detailed plan that justified $\begin{array}{lllllll}1 & 2 & 3 & 4 & 5\end{array}$ his/her ideas.

36. Presents them with information in support of his/her point of view.

37. Explains the reasons for his request. $\begin{array}{llllll}1 & 2 & 3 & 4 & 5\end{array}$ 38. Uses logic to convince them. $\begin{array}{lllll}1 & 2 & 3 & 4 & 5\end{array}$

39. Gives no salary increase or prevented $\begin{array}{llllll}1 & 2 & 3 & 4 & 5\end{array}$ the person from getting a pay raise.

40. Promises (or gives) a salary increase. $1122 \quad 3 \quad 4 \quad 5$ 


$$
\begin{aligned}
& 5=\text { almost always } \\
& 4=\text { often } \\
& 3=\text { occasionally } \\
& 2=\text { seldom } \\
& 1=\text { never }
\end{aligned}
$$

41. Threatens to give them unsatisfactory $1 \begin{array}{llllll}1 & 2 & 3 & 4 & 5\end{array}$ performance evaluations.

42. Threatens them with loss of promotion. $\begin{array}{llllll}1 & 2 & 3 & 4 & 5\end{array}$

43. Offers an exchange (e.g., if you do $\quad \begin{array}{lllll}1 & 2 & 3 & 4 & 5\end{array}$ this for me, I will do something for you).

44. Reminds them of past favors that he $\quad \begin{array}{llllll}1 & 2 & 3 & 4 & 5\end{array}$ did for them.

45. Offers to make a personal sacrifice if $1 \quad 2 \quad 3 \quad 4 \quad 5$ they would do what he/she wants (e.g., work

late, work harder, do their share of the work, etc.).

46. Does personal favors for them.

$\begin{array}{lllll}1 & 2 & 3 & 4 & 5\end{array}$

47. Offers to help if they would do what $\begin{array}{lllll}1 & 2 & 3 & 4 & 5\end{array}$ he/she wants.

48. Makes a formal appeal to higher levels $1 \quad 2 \quad 3 \quad 4 \quad 5$ to back up his/her request.

49. Obtains informal support of higher-ups.1 $22 \quad 3 \quad 4 \quad 5$

50. Files a report about the other person $\begin{array}{llllll}1 & 2 & 3 & 4 & 5\end{array}$ with higher-ups (e.g., his/her superior).

51. Sends them to his/her superior. $\quad \begin{array}{lllll}1 & 2 & 3 & 4 & 5\end{array}$

52. Threatens to notify an outside agency $\begin{array}{llllll}1 & 2 & 3 & 4 & 5\end{array}$ if they do not give in to his/her request.

53. Threatens to stop working with them $\quad \begin{array}{lllll}1 & 2 & 3 & 4 & 5\end{array}$ until they give in.

54. Engages in a work slowdown until they $1 \quad 2 \quad 2 \quad 3 \quad 4 \quad 5$ do what he/she requests.

55. Obtains the support of co-workers to $\quad \begin{array}{llllll}1 & 2 & 3 & 4 & 5\end{array}$ back up his/her request.

56. Obtains the support of his/her subordinates to back up his/her request. 


$$
\begin{aligned}
5= & \text { very satisfied } \\
4= & \text { satisfied } \\
3= & \text { I can't decide } \\
& \text { whether I am } \\
& \text { satisfied or not } \\
2= & \text { dissatisfied } \\
1= & \text { very dissatisfied }
\end{aligned}
$$

ON MY PRESENT JOB, THIS IS HOW I FEEL ABOUT:

57. Being able to keep busy all the time. $\begin{array}{lllll}1 & 2 & 3 & 4 & 5\end{array}$

58. Chance to work alone on the job. $\quad \begin{array}{lllll}1 & 2 & 3 & 4 & 5\end{array}$ 59. The chance to do different things from $1 \quad 2 \quad \begin{array}{llll}3 & 4 & 5\end{array}$ time to time.

60. The chance to be "somebody" in the $\quad \begin{array}{lllll}1 & 2 & 3 & 4 & 5\end{array}$ community.

61. The way my boss handles his men. $\quad \begin{array}{llllll}1 & 2 & 3 & 4 & 5\end{array}$

62. The competence of my supervisor in $\quad \begin{array}{llllll}2 & 2 & 3 & 4 & 5\end{array}$ making decisions.

63. Being able to do things that don't go $1 \begin{array}{llllll}2 & 3 & 4 & 5\end{array}$ against my conscience.

64. The way my job provides steady employment.

65. The chance to do things for other $\quad \begin{array}{lllll}1 & 2 & 3 & 4 & 5\end{array}$ people.

66. The chance to tell people what to do. $\begin{array}{lllll}1 & 2 & 3 & 4 & 5\end{array}$

67. The chance to do something that makes $\begin{array}{llllll}1 & 2 & 3 & 4 & 5\end{array}$ use of my abilities.

68. The way company policies are put into $1 \quad \begin{array}{lllll} & 2 & 3 & 4 & 5\end{array}$ practice.

69. My pay and the amount of work I do. $\quad \begin{array}{lllll}1 & 2 & 3 & 4 & 5\end{array}$

70. The chances for advancement on this $\quad \begin{array}{llllll}1 & 2 & 3 & 4 & 5\end{array}$ job.

71. The freedom to use my own judgment. $\quad \begin{array}{llllll}1 & 2 & 3 & 4 & 5\end{array}$

72. The chance to try my own methods of $\quad \begin{array}{llllll}1 & 2 & 3 & 4 & 5\end{array}$ doing the job. 
73. The working conditions.

$\begin{array}{lllll}1 & 2 & 3 & 4 & 5\end{array}$

74. The way my co-workers get along with $1 \begin{array}{lllllll} & 2 & 3 & 4 & 5\end{array}$ each other.

75. The praise I get for doing a good job. $\begin{array}{llllll}1 & 2 & 3 & 4 & 5\end{array}$

76. The feeling of accomplishment I get $\quad \begin{array}{lllllll}1 & 2 & 3 & 4 & 5\end{array}$ from the job.

During an average or typical week, how many hours do you usually work at this job?

The number of people in your workgroup you based your responses on is

The total number of people (including superiors, peers, and subordinates) in your department or work unit is 
Form B

\section{DIRECTIONS}

I am conducting research on how managers direct and influence behavior of their subordinates. As a starting point, I am attempting to operationally define and measure specific work behaviors used to influence coworker's actions. I am only interested in how supervisors use these behaviors and ask you to please respond by circling the appropriate number to describe how your supervisor directs your workgroup. Your survey will not be seen by anyone but myself and your responses will be confidential, anonymous, and reported in grouped form only. I hope you will now share with me how you see your supervisor using the following behaviors in directing subordinates' work activities. Please feel free to contact me if you have any questions about this study. Thank you for your assistance.

MY SUPERVISOR CAN ...

$$
\begin{aligned}
& 5=\text { strongly agree } \\
& 4=\text { agree } \\
& 3=\text { neither agree nor } \\
& 2 \text { disagree } \\
& 2=\text { disagree } \\
& 1=\text { strongly disagree }
\end{aligned}
$$

1. Promote them or recommend them for $\begin{array}{lllllll}1 & 2 & 3 & 4 & 5\end{array}$ promotion.

2. Demote them or recommend for promotion.

3. Advise and assist them.

$\begin{array}{lllll}1 & 2 & 3 & 4 & 5\end{array}$

4. Set the example and rely upon them to follow his/her example.

5. Expect that his/her orders and requests will be carried out because he/she is the boss and they will not question an order from a superior.

6. Recommend them for awards or for announcements of recognition.

$\begin{array}{lllll}1 & 2 & 3 & 4 & 5\end{array}$

$\begin{array}{lllll}1 & 2 & 3 & 4 & 5\end{array}$

$\begin{array}{lllll}1 & 2 & 3 & 4 & 5\end{array}$

7. Make on-the-spot corrections.

$\begin{array}{lllll}1 & 2 & 3 & 4 & 5\end{array}$




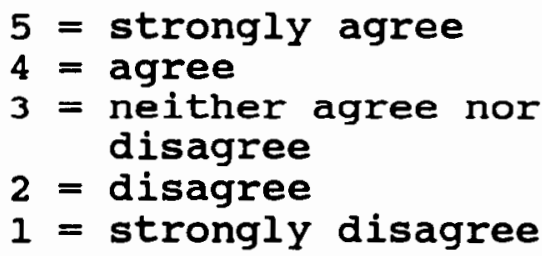

8. Use his/her good relationship with $\quad \begin{array}{lllll}2 & 3 & 4 & 5\end{array}$ them to get the job done.

9. Let them know that he/she has a right $\begin{array}{llllll}1 & 2 & 3 & 4 & 5\end{array}$ to expect that his/her directions will

be followed.

10. Give them high performance ratings. $\begin{array}{llllll}1 & 2 & 3 & 4 & 5\end{array}$

11. Give them low performance ratings, $\begin{array}{llllll}1 & 2 & 3 & 4 & 5\end{array}$

12. Give them interesting, challenging $1 \begin{array}{lllll}2 & 3 & 4 & 5\end{array}$ assignments.

13. Rely upon them to get the job done $\begin{array}{llllll}1 & 2 & 3 & 4 & 5\end{array}$ because they don't want to let him/her down.

14. Emphasize that he/she probably has $1 \begin{array}{lllll}2 & 3 & 4 & 5\end{array}$ information that they do not have and therefore a good reason for any direct request or order.

15. Praise them.

$\begin{array}{lllll}1 & 2 & 3 & 4 & 5\end{array}$

16. Criticize them.

$\begin{array}{lllll}1 & 2 & 3 & 4 & 5\end{array}$

17.Give them boring, routine assignments.1 $2 \begin{array}{llll}2 & 3 & 4 & 5\end{array}$

18. Count on them to believe that it is $1 \quad 2 \quad 3 \quad 4 \quad 5$ to their advantage as much as it is to

his/hers for them to cooperate with him/her.

19. Give them extra time off as a reward. $\begin{array}{llllll}1 & 2 & 3 & 4 & 5\end{array}$

20. Give them extra work as punishment. $\begin{array}{llllll}1 & 2 & 3 & 4 & 5\end{array}$

21. Get them to accomplish the work by $\begin{array}{llllll}1 & 2 & 3 & 4 & 5\end{array}$ demonstrating that he/she knows how to perform the task.

22. Recommend them for formal

$\begin{array}{lllll}1 & 2 & 3 & 4 & 5\end{array}$

disciplinary action or reprimands.

23. Impress them with his/her overall $\quad 1 \quad 2 \quad 3 \quad 4 \quad 5$ competence and ability. 


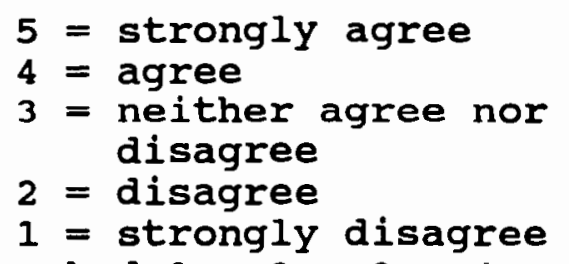

24.Simply order them to do what is asked.1 $2 \begin{array}{llll}2 & 3 & 4 & 5\end{array}$

25. Demand that they do what he/she $\quad \begin{array}{lllll}1 & 2 & 3 & 4 & 5\end{array}$ requests.

26. Bawl them out. $\quad 1 \quad \begin{array}{lllll}2 & 3 & 4 & 5\end{array}$

27. Set a time deadine for them to do $\begin{array}{llllll}1 & 2 & 3 & 4 & 5\end{array}$ what he/she asks.

28. Tell them that the work must be done $1 \quad 2 \quad 3 \quad 4 \quad 5$ as ordered or they should propose a better way.

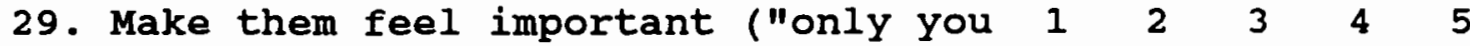
have the brains, talent to this").

30. Act very humbly to them while making $\begin{array}{llllll}1 & 2 & 3 & 4 & 5\end{array}$ his/her request.

31. Act in a friendly manner prior to $1 \begin{array}{lllll}2 & 3 & 4 & 5\end{array}$ asking for what he/she wants.

32. Make them feel good about him/her $\quad \begin{array}{lllll}1 & 2 & 3 & 4 & 5\end{array}$ before making his/her request.

33. Sympathize with them about the added $\begin{array}{llllll}1 & 2 & 3 & 4 & 5\end{array}$ problems that his/her request has caused.

34. Wait until they appear in a $\quad 1 \quad 1 \quad 2 \quad 3 \quad 4 \quad 5$ receptive mood before asking.

35. Write a detailed plan that justified $1 \quad 2 \quad 2 \quad 3 \quad 4 \quad 5$ his/her ideas.

36. Present them with information in

$1 \quad 2 \quad 3 \quad 4 \quad 5$

support of his/her point of view.

37. Explain the reasons for his/her $\quad \begin{array}{lllll}2 & 3 & 4 & 5\end{array}$ request.

38. Use logic to convince them. $\quad 1 \quad \begin{array}{lllll}2 & 3 & 4 & 5\end{array}$

39. Give no salary increase or prevented $1 \quad 2 \quad \begin{array}{lllll} & 3 & 4 & 5\end{array}$ the person from getting a pay raise.

40. Promise (or give) a salary increase. $\begin{array}{llllll}1 & 2 & 3 & 4 & 5\end{array}$ 


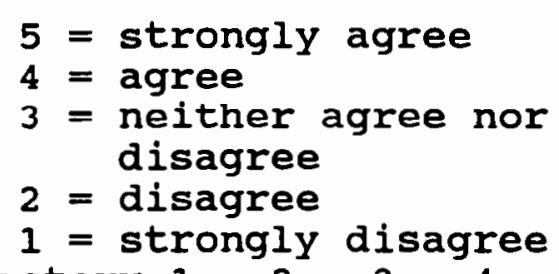

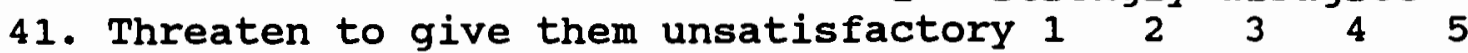
performance evaluations.

42. Threaten them with loss of promotion. $\begin{array}{llllll}1 & 2 & 3 & 4 & 5\end{array}$

43. Offer an exchange (e.g., if you do $11 \quad 2 \quad 3 \quad 4 \quad 5$ this for me, I will do something for you).

44. Remind them of past favors that $\quad \begin{array}{lllll}1 & 2 & 3 & 4 & 5\end{array}$ he/she did for them.

45. Offer to make a personal sacrifice $\quad \begin{array}{lllll}1 & 2 & 3 & 4 & 5\end{array}$ if they would do what he/she wants (e.g., work late, work harder, do their share of the work, etc.).

46. Do personal favors for them. $\quad \begin{array}{lllll}1 & 2 & 3 & 4 & 5\end{array}$

47. Offer to help if they would do what $\begin{array}{lllll}1 & 2 & 3 & 4 & 5\end{array}$ he/she wants.

48. Make a formal appeal to higher levels to back up his/her request.

$\begin{array}{lllll}1 & 2 & 3 & 4 & 5\end{array}$

49. Obtain the informal support of higher-ups.

50. File a report about the other person $1 \quad 2 \quad 3 \quad 4 \quad 5$ with higher-ups (e.g., his/her superior).

51. Send them to his/her superior.

$\begin{array}{lllll}1 & 2 & 3 & 4 & 5\end{array}$

52. Threaten to notify an outside agency $\begin{array}{llllll}1 & 2 & 3 & 4 & 5\end{array}$ if they do not give in to his/her request.

53. Threaten to stop working with them $1 \quad \begin{array}{lllll}2 & 3 & 4 & 5\end{array}$ until they give in.

54. Engage in a work slowdown until they $1 \quad 2 \quad 3 \quad 4 \quad 5$ do what he/she requests.

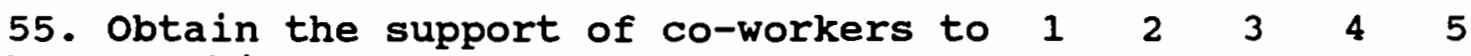
back up his/her request.

56. Obtain the support of his/her subordinates to back up his/her request. 


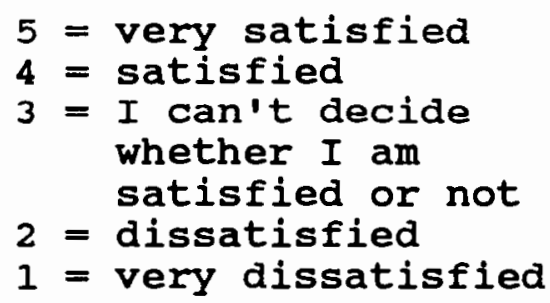

ON MY PRESENT JOB, THIS IS HOW I FEEL ABOUT:

57. Being able to keep busy all the time. $\begin{array}{lllll}1 & 2 & 3 & 4 & 5\end{array}$

58. The chance to work alone on the job. $\begin{array}{llllll}1 & 2 & 3 & 4 & 5\end{array}$

59. The chance to do different things $\quad \begin{array}{llllll}2 & 2 & 3 & 4 & 5\end{array}$

from time to time.

60. The chance to be "somebody" in the $1 \quad \begin{array}{lllll}2 & 3 & 4 & 5\end{array}$ community.

61. The way my boss handles his men. $\quad 1 \quad 2 \quad 3 \quad 4 \quad 5$

62. The competence of my supervisor $\quad 1 \quad \begin{array}{lllll}2 & 3 & 4 & 5\end{array}$

in making decisions.

63. Being able to do things that don't go $1 \quad 2 \quad \begin{array}{llll}3 & 4 & 5\end{array}$ against my conscience.

64. The way my job provides steady $\quad \begin{array}{llllll} & 2 & 3 & 4 & 5\end{array}$ employment.

65. The chance to do things for others. $\begin{array}{llllll}1 & 2 & 3 & 4 & 5\end{array}$

66. The chance to tell people what to do. $\begin{array}{llllll}2 & 2 & 3 & 4 & 5\end{array}$

67. The chance to do something that makes $\begin{array}{llllll}1 & 2 & 3 & 4 & 5\end{array}$ use of my abilities.

68. The way company policies are put into $1 \quad \begin{array}{lllll}2 & 3 & 4 & 5\end{array}$ practice.

69. My pay and the amount of work I do. $\quad \begin{array}{llllll}1 & 2 & 3 & 4 & 5\end{array}$

70. The chances for advancement on this. $\begin{array}{llllll} & 2 & 3 & 4 & 5\end{array}$ job.

71. The freedom to use my own judgment. $\quad \begin{array}{llllll}1 & 2 & 3 & 4 & 5\end{array}$

72. The chance to try my own methods of $1 \quad \begin{array}{llllll}2 & 3 & 4 & 5\end{array}$ doing the job. 
74. The way my co-workers get along with $1 \quad 2 \quad \begin{array}{lllll}4 & 4 & 5\end{array}$ each other.

75. The praise I get for doing a good. $\quad \begin{array}{llllll}1 & 2 & 3 & 4 & 5\end{array}$ job.

76. The feeling of accomplishment I get $\begin{array}{llllll}1 & 2 & 3 & 4 & 5\end{array}$ from the job.

During an average or typical week, how many hours do you usually work at this job?

The number of people in your workgroup you based your responses on is

The total number of people (including speriors, peers, and subordinates) in your department or work unit is 